\title{
The Role of Urban Agriculture as a Nature-Based Solution: A Review for Developing a Systemic Assessment Framework
}

\author{
Martina Artmann * and Katharina Sartison \\ Leibniz Institute of Ecological Urban and Regional Development, Weberplatz 1, 01217 Dresden, Germany; \\ k.sartison@ioer.de \\ * Correspondence: m.artmann@ioer.de; Tel.: +49-351-46-79-231
}

Received: 20 April 2018; Accepted: 6 June 2018; Published: 9 June 2018

\begin{abstract}
Urbanization and achieving sustainable agriculture are both major societal challenges. By reducing food miles and connecting people with nature, food cultivation in cities has several major advantages. However, due to further urban development (peri-) urban agriculture (UPA) is under threat. To strengthen UPA, we argue for considering UPA as a nature-based solution (NbS) supporting systemic approaches for societal challenges. However, academic knowledge on UPA's contribution to various societal challenges of urbanization is still fragmented. This study addresses the gap by conducting a systemic literature review, incorporating 166 academic articles focusing on the global north. The results of the review show that UPA contributes to ten key societal challenges of urbanization: climate change, food security, biodiversity and ecosystem services, agricultural intensification, resource efficiency, urban renewal and regeneration, land management, public health, social cohesion, and economic growth. The value of UPA is its multifunctionality in providing social, economic and environmental co-benefits and ecosystem services. When implementing UPA, social, institutional, economic, technical, geographical, and ecological drivers and constraints need to be considered. To upscale UPA successfully, the study develops an integrative assessment framework for evaluating the implementation and impact efficiency of UPA. This framework should be tested based on the example of edible cities.
\end{abstract}

Keywords: urban food supply; indicators; ecosystem services; multifunctionality; edible city; systemic solution

\section{Introduction}

Worldwide cities are spatially expanding twice as fast as the urban population [1]. Since land and soil are limited resources, the ongoing trend of urbanization will further increase competition between different kinds of land use such as settlement, transport areas, and arable land [2]. The spatial extension of cities in particular impacts urban and peri-urban agriculture (UPA) negatively [3,4]. According to the Food and Agriculture Organization of the United Nations [5], UPA can be defined as the growing of plants or animals within and around cities and associated activities such as producing and delivering inputs as well as processing and marketing of agricultural products. Urban food is mainly produced at managed agro-ecosystems. In addition, forests, (industrial) rooftop gardens, residential and community gardens, containers on balconies, vacant land, edible landscaping, vertical edible green infrastructure as well as marine and freshwater systems are spaces for urban food products [6-9]. These different forms of UPA produce a broad variety of foods related to plants and animals (e.g., vegetables, fruits, eggs, milk) depending on climate conditions, existing technologies, and cultural preferences [8]. All in all, these different structures and components of UPA contribute to an edible green infrastructure 
with the main aim to contribute to urban food supply [9], which is also the focus of UPA in our study. Between $15-20 \%$ of the world's food is produced in cities worldwide [10].

Compared to rural agriculture the growing of food in cities has some major advantages such as close proximity to markets, providing fresh food as well as reducing transportation costs [10]. Indeed, local food supply through UPA can have multidimensional positive impacts such as reducing negative impacts on the environment through humans, promoting the local economy, and strengthening social cohesion [6-8]. The ongoing loss of agricultural land in urban and peri-urban areas raises in particular the concern of jeopardizing food security [11-13] and the ability to secure the growing demand for food which will increase by $43 \%$ by 2030 [5]. Food security is not only an issue for countries of the global south but also, for instance, for low-income households of the global north, contributing also to economic and social well-being [14]. In addition, food quality is a major concern in cities of the global north and there is an increasing need to provide sustainable locally produced foods $[15,16]$. Despite the increasing demand for UPA in the global north, many papers dealing with UPA address the global south [17]. In order to fill this gap, our study focuses on UPA of the global north.

Through UPA's multidimensional benefits and contribution to societal challenges, such as decreasing food risk, we argue that urban food supply through UPA can be considered as an urban nature-based solution (NbS). The concept of NbS promotes systemic approaches for social, environmental, and economic challenges by supporting, restoring, and maintaining the ecosystem and sustainable urbanization. It is emphasized that $\mathrm{NbS}$ provides innovative solutions to counteract societal challenges by using natural capital to create sustainable economic growth [18]. Current research dealing with urban $\mathrm{NbS}$ focuses in particular on climate resilience in urban areas [19-21]. This may be due to the fact that the concept of NbS was firstly introduced in the late 2000s with the aim of developing solutions for mitigating and adapting to climate change. Since then, they now consider the protection of biodiversity and quality of life as well [22]. Academic knowledge on UPA's contribution to challenges related to urbanization and its co-benefits is still fragmented. For instance, current reviews dealing with UPA focus on multidimensional benefits in general such as ecosystem services or social, economic and environmental contributions [9,23], while neglecting the societal challenges of urbanization which $\mathrm{NbS}$ should contribute to.

Therefore, the overall aim of this study is to provide a systematic review of UPA in the global north and their potential to contribute to major societal challenges and their resulting co-benefits. Besides understanding the potential multidimensional impacts of $\mathrm{NbS}$, there is the need to comprehend how to successfully implement $\mathrm{NbS}$ [21]. This holds also true for UPA. Thus, regulations or designs can influence the success of UPA and institutional framework conditions for the implementation of UPA are argued to need an in-depth understanding for successfully implementing UPA [14,24]. Therefore, this review will not only address UPA impacts to societal challenges and co-benefits but will also synthesize important drivers and constraints of UPA implementation.

The key questions the study aims to answer are: (1) Which societal challenges connected with urbanization can UPA contribute to?, (2) how can UPA be implemented?, and (3) which co-benefits relate to UPA? Based on the findings, an integrative assessment framework will be developed to support the upscaling of UPA as NbS. Thus, upscaling NbS is an important step for mainstreaming $\mathrm{NbS}$ in urban areas [21].

\section{Methods}

\subsection{Review Approach}

The review is based on peer-reviewed papers published in international scientific journals. Although gray literature could have provided interesting insights on UPA, such publications were not included to ensure that only articles with secured high quality standards were involved in the review to improve the evidence on $\mathrm{NbS}$ [18]. Since the concept of NbS encompasses human-environmental interactions, we included papers published from 2010 onwards [25]. To identify relevant papers a 
search of key variables was done in the categories "title, abstract, and keywords" in the ScienceDirect (www.sciencedirect.com) and Scopus (www.scopus.com) databases.

The focus of the review is on the question "How does UPA contribute to societal challenges of urbanization?". This question secures a close link between NbS and UPA. Defining and specifying key challenges is a major prerequisite to developing suitable NbS [26,27]. Since we assume that papers dealing with UPA do not all generally address societal challenges, but also specific challenges and to secure and to define a clear streamline on how UPA can contribute to NbS [18], we pre-selected societal challenges in the light of urbanization supported also by UPA to be relevant for the review. These challenges then function as one of the keyword categories for the database search. Besides societal challenges we included two further variables for the search terms reflecting the focus on the urban environment (variables are: urban, peri-urban, city, municipal) as well as on UPA with its main function of food supply (variables are: agriculture, gardening, farming, cultivation, foraging, forest farming). These terms were chosen because they include basic information and content information which we considered as important to answer the main research questions.

To identify the key societal challenges related to urbanization and UPA we searched documents from high-level policies dealing with $\mathrm{NbS}$ and related concepts such as ecosystem services (direct and indirect benefits by the ecosystem to human well-being [28]) and green infrastructure (strategically planned multi-scale network of different kinds of urban green and blue spaces, e.g., [29]). NbS needs further research, due to its broad definition as to how NbS can be linked to similar concepts [27]. We chose high-level policies because it is argued that the uptake of such concepts by planning is supported by these policies such as shown in the example of urban ecosystem services [30]. Based on Raymond et al. (2017) [21] and high-level policies, we identified ten key societal challenges UPA can contribute to (see Table 1). Based on the key challenges, we refined the wording and additional fields of action we thought needed to be considered, focusing on UPA such as based on key literature review, e.g., [31]. All text queries used for each challenge and the number of papers identified in total are listed in Supplementary Material S1. The search was conducted in September 2017.

Table 1. Key societal challenges and related action areas of UPA.

\begin{tabular}{clc}
\hline No. & \multicolumn{1}{c}{ Challenges and Relevant Fields of Action } & References \\
\hline 1 & Climate change (including climate change adaption and mitigation, & carbon sequestration) \\
2 & Food security (including food safety, food justice) & {$[18,21,32-35]$} \\
3 & Biodiversity and ecosystem services & {$[32,35]$} \\
4 & Agricultural intensification (including organic farming, sustainable agriculture) & {$[18,32-35]$} \\
5 & Resource efficiency (including energy efficiency, water protection, urban water, life & {$[18,34,35]$} \\
6 & cycle assessment) & {$[18,33-35]$} \\
7 & Urban renewal and regeneration (including abandoned land, brownfields, vacancy) & {$[18,21,33]$} \\
8 & green space managementuding land take, soil sealing, soil degradation, soil erosion, & {$[18,32-35]$} \\
9 & Public health (including, well-being, quality of life) & {$[18,21,32-35]$} \\
10 & Eocial cohesion (including social justice, participation, awareness, civic agriculture) & {$[18,21,33-35]$} \\
\hline & & {$[18,21,33-35]$} \\
\hline
\end{tabular}

The database search resulted in 1590 papers. To specify our review we applied the following inclusion criteria and we selected papers that:

(1) focus on urban areas in the global north,

(2) address UPA with a focus on food supply,

(3) deal at least with one of the ten challenges,

(4) are published in English,

(5) are published from 2010 onwards and 
(6) provide an empirical study (reviews, explorative or conceptual papers were excluded to ensure that primary data on UPA is gained).

We read the abstracts and if necessary the whole paper to determine if the study fulfilled all requirements and skipped papers which were not relevant for the study or were double listed within the same or in two or more challenges. If papers appeared in more than one challenge we filtered the most relevant challenge the paper focuses on (i.e., depending on research questions and objectives) and noted the additional challenges. The additional challenge was only noted if the study focus addresses the challenge and it was not sufficient that a challenge was mentioned only peripherally. The selection process then resulted in 166 articles which were included in the review for a detailed analysis.

\subsection{Analysis Approach of Identified Papers}

To secure a consistent data extraction and analysis we developed a standardized data extraction sheet. The articles were analyzed by the authors and trained project staff. The results were cross-checked by the leading author to streamline all findings at the end of the process. The overall analysis of the review was done for each challenge separately reflecting the concept of $\mathrm{NbS}$. Besides, the focus of the analysis is the identification of factors influencing the implementation and co-benefits of UPA and its related societal challenges. Therefore, the concepts of green infrastructure and ecosystem services are reflected in the analysis criteria. By doing so, the study contributes to the conceptual understanding of $\mathrm{NbS}$ in relation to UPA. Thus, the concepts of $\mathrm{NbS}$, ecosystem services and green infrastructure are mutually reinforcing each other, emphasizing the dependences between society and nature [27].

Taking this conceptual background into account, the analysis of the co-benefits mainly includes aspects of $\mathrm{NbS}$ and green infrastructure planning connected to governance aspects [27,29]. Co-benefits comprise the environmental, social, and economic multifunctionality of UPA [36]. In our analysis we embed ecosystem services of UPA considering providing, regulatory and cultural services [37]. Since NbS [27] as well as green infrastructure [38] and ecosystem services [37] stand out for their socio-ecological approach, actors mentioned in the course of the implementation and affected by impacts are considered for the implementation and impacts. Table 2 summarizes the analysis framework.

Table 2. Keywords of the analysis approach.

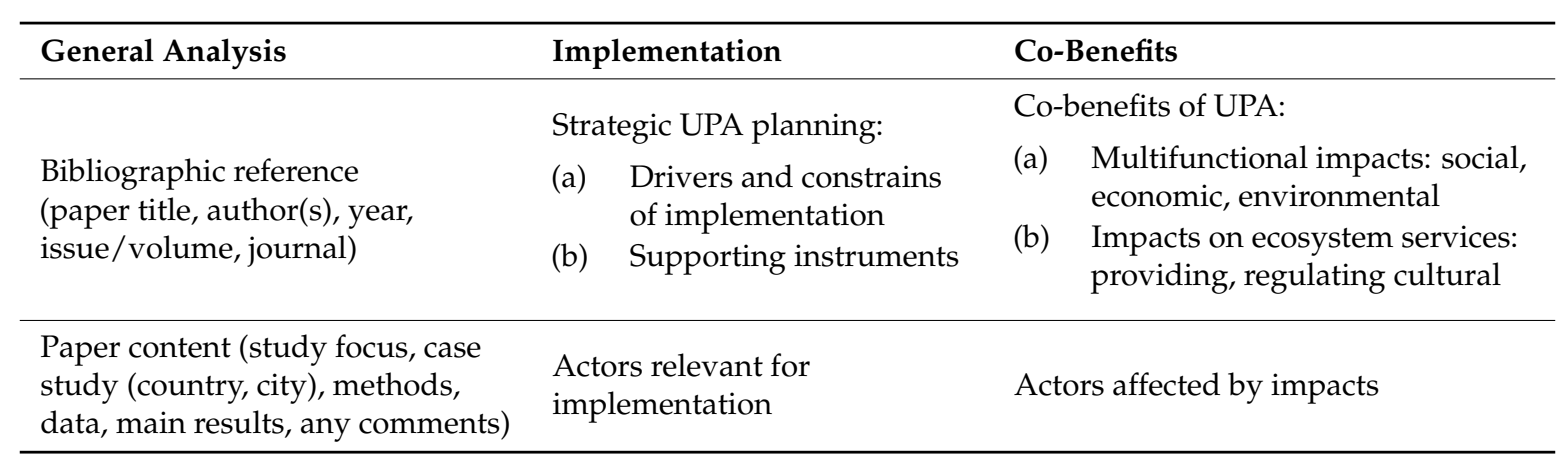

\section{Results}

After giving a general overview of the review results (see Section 3.1) this section answers the questions (see Section 1) (1) how UPA contributes to societal challenges connected with urbanization according to Table 1 (see Section 3.2), (2) which co-benefits relate to UPA (see Section 3.3) and (3) how UPA can be implemented (see Section 3.4). 


\subsection{General Overview and Patterns}

\subsubsection{Temporal Development}

Figure 1 illustrates that UPA is a growing research topic. In particular from 2013 onwards the number of published papers increased. Interestingly, no papers dealing with challenge 1 (climate change) were published before 2017.

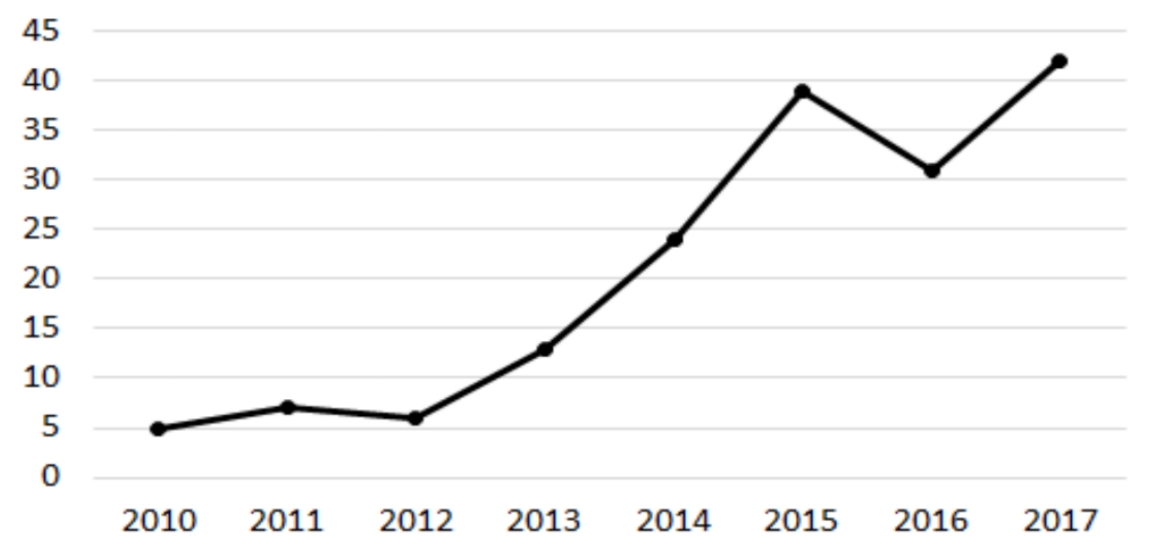

(C) Artmann \& Sartison, IOER 2018

Figure 1. Number of published papers between 2010-2017. (Note: It must be considered that not all 2017 papers might have been published at the time of the review. In addition, two papers published in 2018 were included in 2017 since this was the year they were first published online and thus appeared in the database search).

\subsubsection{Geographical Pattern}

The majority of the case studies address a single case study city (81\%) and single country (92\%). $11 \%$ and $3 \%$ of the papers include two or three case studies, $7 \%$ and $1 \%$ compare two and three countries respectively. Only three papers include a comparative study between the global south and global north focusing on Manila (Philippines) [39], Dar es Salam (Tanzania) [40], and Sebakwe (Zimbabwe) [41]. Figure 2 illustrates an overview of the geographical distribution of the case studies focusing on countries of the global north. The analysis shows that most studies were done in Europe, in particular in central Europe (Germany and Switzerland) and southern Europe (Spain and Italy), as well as in the USA. Little research was found from Japan, Singapore, and South Korea, and no research was found, for instance in Russia and Turkey. This could be due to only English language studies being involved in the review. The focus on the case study cities is on large and growing cities: the majority of the case studies investigated (46\%) had a population over 500,000 residents, $31 \%$ between 100,000 and 500,000 and 23\% less than 100,000 residents; $80 \%$ of the case study cities had a growing population, $16 \%$ of the cities were shrinking in terms of population size (focus of reference years: 2006-2016). In total, 234 case studies were conducted. 


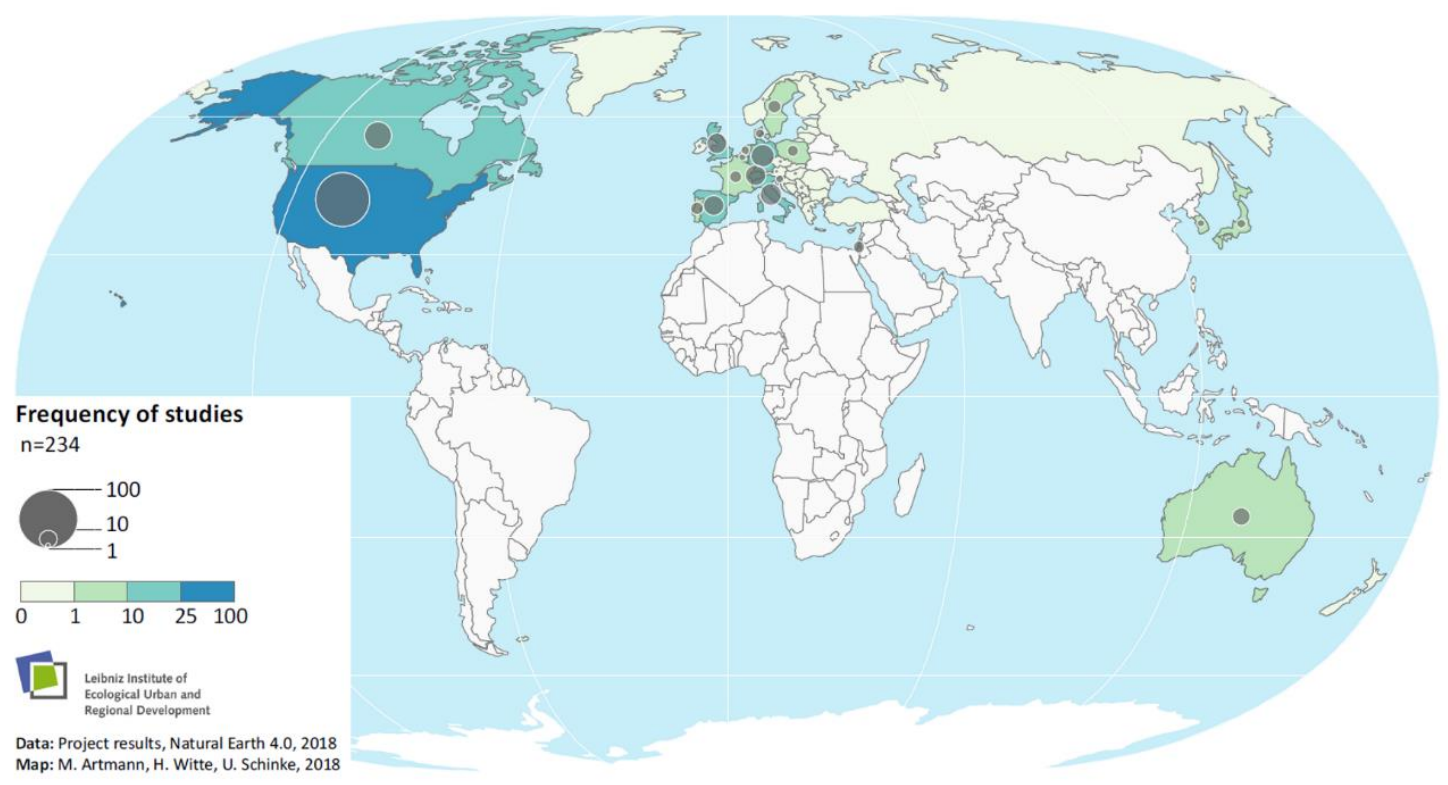

Figure 2. Geographical distribution of case studies per country with focus on global north.

\subsubsection{Major Groups of Papers}

The papers can be grouped into three major categories each including two sub-categories according to their research objectives (papers can also have several foci as well):

(1) Papers focusing on threats related to UPA and the challenges:

(1a) Those that study negative impacts from UPA impacting a challenge (e.g., fertilizer used for UPA jeopardizes challenge 3 , biodiversity) $(n=14)$.

(1b) Those that reflect negative impacts to UPA through challenges (e.g., challenge 1, climate change, increases the risk of floods jeopardizing UPA) $(n=6)$.

(2) Papers focusing on opportunities related to UPA and the challenges:

(2a) Those that investigate positive impacts from UPA on a challenge (e.g., urban gardening contributing to social cohesion (challenge 9) $(n=90)$.

(2b) Those that reflect positive impacts to UPA through impacts related to a challenge (e.g., challenge 1 , climate change, and the related impact urban heat island promote food supply of exotic fruits) $(n=16)$.

(3) Papers having an open focus (negative/positive impacts) related to UPA and the challenges:

(3a) Those that study positive and negative impacts resulting from UPA on a challenge (e.g., assessing the environmental performance of food production by rooftop gardens using a life cycle assessment approach (challenge 5$))(n=21)$.

(3b) Those that consider positive and negative impacts to UPA through impacts related to a challenge (e.g., assessing the soil quality of urban brownfields (challenge 6) used for urban gardening) $(\mathrm{n}=24)$.

Since our main research objective is to analyze the role of UPA as NbS and its related co-benefits, we included for the further analysis only papers dealing with study focus 2 or 3 and excluded papers, which were only focusing on 1 resulting in a total of 150 papers. Supplementary Material S2 shows all papers per challenge and study focus. 


\subsection{UPA Contributing to Societal Challenges of Urbanization}

Figure 3 illustrates the distribution of the papers per challenge. Most papers focus on ecosystem services and biodiversity (challenge 3), followed by land management (challenge 7) and food security (challenge 2). The least investigated challenges are agricultural intensification (challenge 4), climate change (challenge 1) and public health (challenge 8). The following chapter delves deeper into the single challenges and presents the results respectively.

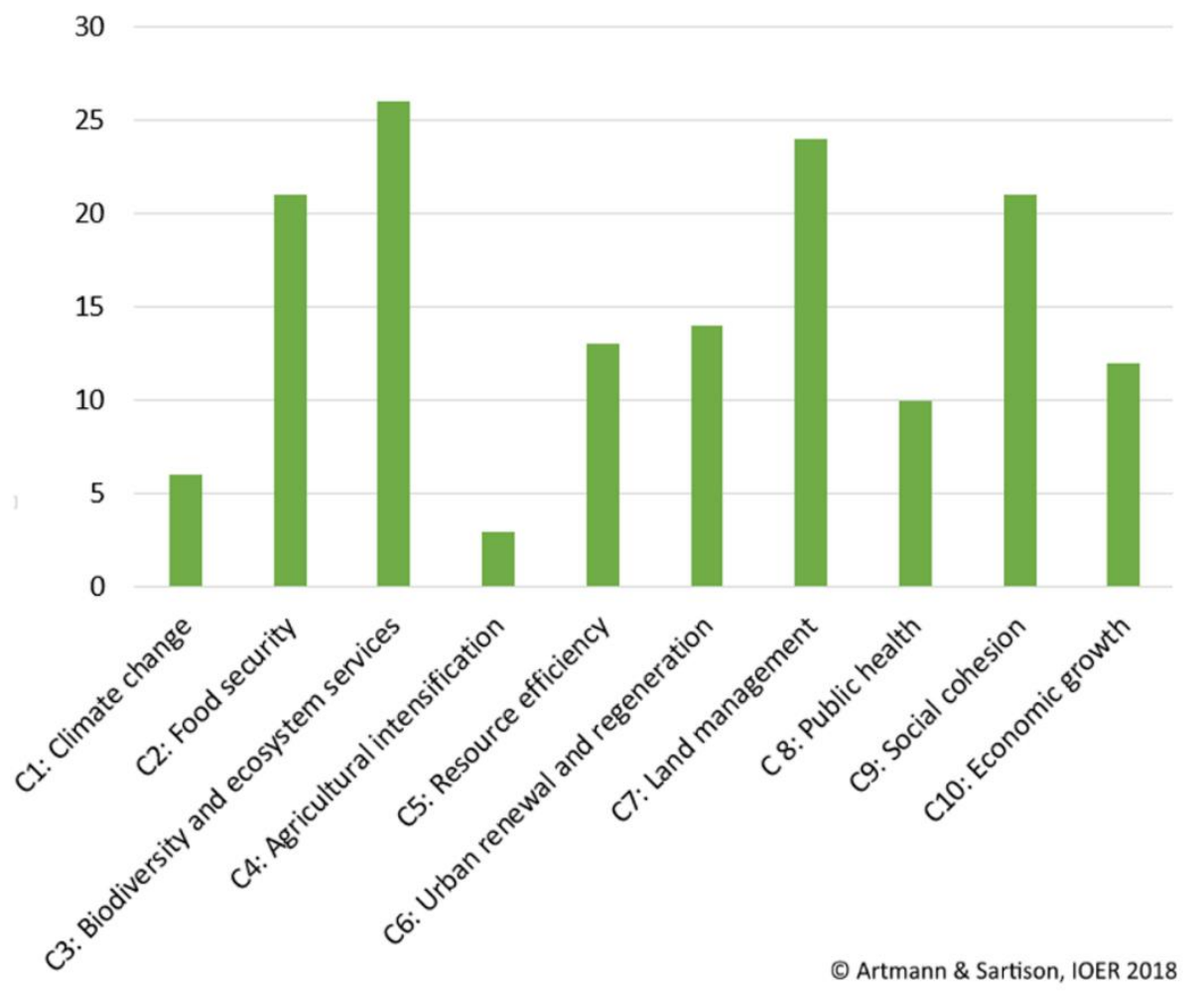

Figure 3. Distribution of the papers per challenge related to group 2 and 3 (in $\%, n=150$ ). (Note: Challenge $1(\mathrm{C} 1)$ : climate change (including climate change adaption and mitigation, carbon sequestration); challenge 2 (C2): food security (including food safety, food justice); challenge 3 (C3): biodiversity and ecosystem services; challenge 4 (C4): agricultural intensification (including organic farming, sustainable agriculture); challenge 5 (C5): resource efficiency (including energy efficiency, water protection, urban water, life cycle assessment); challenge 6 (C6): urban renewal and regeneration (including abandoned land, brownfields, vacancy); challenge 7 (C7): land management (including land take, soil sealing, soil degradation, soil erosion, green space management, governance, green infrastructure); challenge 8 (C8): public health (including, well-being, quality of life); challenge 9 (C9): social cohesion (including social justice, participation, awareness, civic agriculture); challenge 10 (C10): economic growth (including green jobs, innovation, cost-effectiveness).

\subsubsection{Climate Change}

In the light of ongoing urbanization worldwide, impacts resulting from climate change (e.g., floods, droughts) will harm cities and people living there. Cities being vulnerable to climate change should take a leading position in implementing climate change mitigation and adaption [42].

In this regard, it is surprising that only six papers included in the review focus on the impact by UPA on climate change [42], which is the second least important challenge according to the number of papers. This might be due to the fact that impacts by climate change on cities are considered in a more general way, not focusing solely on UPA. However, empirical studies investigating UPA's potential in adapting and mitigating to climate change found that food grown in cities can be an 
important source in reducing greenhouse gas emissions such as carbon dioxide $\left(\mathrm{CO}_{2}\right)$, for instance by reducing food mileage [43], growing vegetables in residential gardens [44] or using soilless crops [45]. Besides reflecting climate change as a challenge for urbanization, climate change can also offer UPA opportunities in growing food such as reflected in a case study in Toronto (Canada) [46]. Warmer winters and longer and hotter growing seasons in the city of Toronto provide the possibility to grow warmer-climate crops that would, without the urban heat island effect, not grow successfully [46]. However, heat and related water restrictions put food production in urban gardens such as in California (USA) at risk. Lin et al. (2018) showed that, among other things, tallest vegetation, tree and shrub species richness, grass and mulch cover contribute to cooling factors showing that an appropriate garden management influences the potential of UPA contributing to climate change mitigation and adaption [47].

\subsubsection{Food Security}

Food security demands that "all people, at all times, have physical, social and economic access to sufficient, safe and nutritious food which meets their dietary needs and food preferences for an active and healthy life" [48], p. 29. That means that food security includes access to food in terms of quantity and quality and personal preferences.

In our review the contribution of UPA to food security is, together with challenge 9 , the third most focused one with 21 papers. To understand the capacity of urban ecosystems contributing to food supply there is a range of estimations on different scales, types of food supplied and farming management. The review shows that the potential degree of meeting a city's food self-sufficiency varies between case studies (see Table 3). One study suggests that urban food supply can fully be met by UPA for high-yield fresh vegetables and fruits using areas on a ground level (e.g., vacant land, residential and commercial areas) and flat roofs [49]. However, further studies suggest that meeting the vegetable demand of the population depends on the management intensity of urban farming [7], the type of food provided (fruit or vegetable [50]), the individual food consumption behavior (e.g., meat vs. plant-based nutrition [51]), and supply of suitable space for UPA. For instance, a study in Singapore, focusing solely on rooftop farming, suggests that the domestic demand for vegetables can be satisfied by $35.5 \%$ [52]. The fact that only focusing on rooftop farming might not meet the consumption demand was also proven in a study in Rubí (Spain) [53]. To conclude, the studies can hardly be compared with each other. For instance, the studies differ strongly in their modeling and analysis methods, often neglecting differences in consumption behavior (e.g., age, sex) and preferences, which influences food supply and demand (see Table 3). Also the assumptions of potential areas for UPA are often simple. Not all horizontal areas are eligible for UPA, for instance shady spaces or areas needed for other functions, however, the whole horizontal area was used for calculation in the Munich (Germany) study [50].

When dealing with UPA contributing to food security there is the need to consider socio-economic implications. For instance, people on low incomes rely on urban gardening due to lacking access to food [54]. UPA also supports food resilience after natural disasters, as shown in a case study in Tokyo (Japan) [55]. In general, studies suggest that urban gardening does not only increase the quantitative access to food but also food security in terms of quality by promoting a more nutritious diet irrespective of income level $[56,57]$. The growing interest of residents in organic and local food is a major opportunity to promote the implementation of UPA further [58]. 
Table 3. Overview on methods and outcomes calculating urban food supply.

\begin{tabular}{|c|c|c|c|c|c|c|}
\hline $\begin{array}{l}\text { Case Study } \\
\text { (City/Country) }\end{array}$ & Land Analyzed for UPA & Food Assessed & Methods Used & Food Demand & $\begin{array}{c}\text { Degree of Potential } \\
\text { Food-Self-Sufficiency/Food Supply }\end{array}$ & Reference \\
\hline Boston/USA & $\begin{array}{l}\text { City: rooftop and ground } \\
\text { level areas (vacant, } \\
\text { residential, commercial } \\
\text { parcels suitable for } \\
\text { primary agriculture) }\end{array}$ & $\begin{array}{l}\text { Fruit and vegetables (dark } \\
\text { green vegetables, tree fruits } \\
\text { considering local climate } \\
\text { and different } \\
\text { production practices) }\end{array}$ & $\begin{array}{l}\text { GIS-based model for UPA } \\
\text { site suitability analysis, } \\
\text { spatially averaged crop } \\
\text { yield for estimating } \\
\text { food yields }\end{array}$ & $\begin{array}{l}\text { USA average annual intake } \\
\text { of } 197 \mathrm{~kg} \text { fresh fruit } \\
\text { and vegetables }\end{array}$ & $\begin{array}{l}\text { Ca. } 1 \text { million people ( } 50 \% \text { larger than } \\
\text { the case study city's population) }\end{array}$ & [49] \\
\hline Montréal/Canada & $\begin{array}{l}\text { City: residential gardens, } \\
\text { industrial rooftops, } \\
\text { vacant space }\end{array}$ & $\begin{array}{l}\text { Vegetables (representative } \\
\text { sample of vegetable } \\
\text { proportions and varieties } \\
\text { considering the local } \\
\text { climate and } \\
\text { costumer preferences) }\end{array}$ & $\begin{array}{l}\text { Spatial analysis, multiple } \\
\text { production scenarios } \\
\text { (high-intensity vs. } \\
\text { low-intensity) according to } \\
\text { secondary data }\end{array}$ & $\begin{array}{l}\text { Recommendation } \\
\text { according to international } \\
\text { organizations: } 121 \mathrm{~kg} / \text { year } \\
\text { of fresh vegetables } \\
\text { per person }\end{array}$ & $\begin{array}{l}\text { All vacant land: low-intensity } \\
\text { yields: } 45 \% \text {, high-intensity } \\
\text { yields: } 75 \% \text {; } \\
\text { (2) All industrial rooftops: } 277 \% \text {; } \\
\text { (3) Residential yards: } \\
\text { low-intensity yields: } 92 \% \text {, } \\
\text { high-intensity yields: } 128 \% \text {; } \\
\text { (4) Vacant areas, residential yards, } \\
\text { industrial rooftops: } \\
\text { low-intensity yields: } 379 \% \text {, } \\
\text { high-intensity yields: } 446 \%\end{array}$ & [7] \\
\hline Munich/Germany & $\begin{array}{l}\text { Single district: unsealed } \\
\text { one and two-story } \\
\text { buildings, unsealed and } \\
\text { sealed surfaces like car } \\
\text { parks, green spaces, flat } \\
\text { roofs, roofs with an angle } \\
\text { of }<15^{\circ} \text {, building facades }\end{array}$ & $\begin{array}{l}\text { Apples, white } \\
\text { cabbage, grapes }\end{array}$ & Spatial analysis & $\begin{array}{l}\text { Recommendation } \\
\text { according to WHO: } \\
146 \mathrm{~kg} / \text { year fruits and } \\
\text { vegetables per person } \\
\text { (discounting children } \\
\text { under the age of three since } \\
\text { they consume less food) }\end{array}$ & $\begin{array}{l}66 \% \text { of demand for fruit, } 246 \% \text { of } \\
\text { demand for vegetables }\end{array}$ & [50] \\
\hline $\begin{array}{l}\text { Tampines New } \\
\text { Town/Singapore }\end{array}$ & $\begin{array}{l}\text { City: rooftop areas of all } \\
\text { slab block } \\
\text { public housings }\end{array}$ & $\begin{array}{l}\text { Vegetable produced by } \\
\text { inorganic hydroponics }\end{array}$ & Spatial analysis & $\begin{array}{l}\text { Singapore's vegetable } \\
\text { needs (no further } \\
\text { definition) }\end{array}$ & $35.5 \%$ of Singapore's vegetable needs & [52] \\
\hline Adelaide/Australia & $\begin{array}{l}\text { Single district: } \\
\text { Backyard gardens }\end{array}$ & Crop yields, meat yields & $\begin{array}{l}\text { Linear Programming } \\
\text { (considering different } \\
\text { dietary preferences) }\end{array}$ & $\begin{array}{l}\text { Default food group intake } \\
\text { ranges (considering lower } \\
\text { and upper bounds } \\
\text { (according to age, sex, } \\
\text { height and level of physical } \\
\text { activity) for energy and } \\
\text { protein, plus sixteen "food } \\
\text { groups" representing a } \\
\text { nutritionally diverse diet) }\end{array}$ & $10-15 \%$ of dietary protein & [51] \\
\hline Rubí/Spain & $\begin{array}{l}\text { City/site: Rooftop } \\
\text { greenhouses }\end{array}$ & Tomatoes & Spatial analysis & $\begin{array}{l}\text { Case study's average yearly } \\
\text { consumption }\end{array}$ & $\begin{array}{l}50 \% \text { of the case study's total } \\
\text { population }\end{array}$ & [53] \\
\hline
\end{tabular}




\subsubsection{Biodiversity and Ecosystem Services}

Compared to traditional engineered solutions, $\mathrm{NbS}$ such as organic farming are argued to be cost-effective, long-term solutions providing multiple benefits which can be mirrored by the ecosystem services they provide [59].

That UPA has multiple benefits is confirmed in the third challenge analyzing its contribution to biodiversity and ecosystem services. In fact, most papers focus on this challenge. The majority of the studies deal with the mapping and assessing of multiple ecosystem services provided by different kinds of UPA e.g., [60-62]. However, some studies focus solely on one benefit, mostly on biodiversity (8 papers, e.g., [63-65], followed by regulating services (7 papers) mainly related to run-off mitigation [66,67], maintenance of soil quality [68,69], microclimate regulation [70], and pollination [71]. The focus of the studies dealing with ecosystem services and biodiversity is clearly on community gardens (14 papers, e.g., [60,61,72], followed by private/home food gardens (6 papers, e.g., [73-75] and allotment gardens (5 papers, e.g., $[60,68,76])$. Urban and peri-urban farms $[75,77]$ or rooftop gardens [78] are rarely investigated within this challenge.

Papers analyzing multiple ecosystem services focusing in particular on community, allotment, and home gardens confirm that UPA can provide a bundle of ecosystem services including cultural, provisioning, and regulating ecosystem services and support biodiversity $[61,71,74,76]$. Ranking the importance of several ecosystem services according to the beneficiaries' needs and use, the studies are not always consistent. Two studies suggest that in particular cultural ecosystem services are of crucial importance $[60,76]$ and the importance of gardens for food supply is decreasing [76]. In contrast, another study found that food production has a high importance [61].

Only two papers discussed trade-offs or synergies among ecosystem services [72,73]. The papers suggest that there might be trade-offs between food supply and microclimate regulation as well as between food production and biodiversity. For instance, trees which are important for climate regulation have to be removed in favor of food production [73]. Trade-offs between biodiversity and micro-climate regulation can also be confirmed suggesting that site characteristics (e.g., site size) strongly influence trade-offs [73].

\subsubsection{Agricultural Intensification}

To fulfil the increasing demand for agricultural crops in the light of the increasing global population, the intensification of existing cropland is one opportunity besides land clearing. However, at present agricultural intensification is already connected to environmental impacts such as contributing to global greenhouse gas emissions, which results among other things from fertilization, which also jeopardizes the ecosystem [79]. Agricultural intensification is also identified as one main key European pressure threatening ecosystem degradation [18]. In contrast to agricultural intensification, organic agriculture is argued to be a $\mathrm{NbS}$ as it reduces soil erosion, supports biodiversity and is socially and economically sustainable [59].

As an answer to these challenges, this topic seems not to be relevant in urban settings and we only identified three papers within this challenge [80-82], which is the most underrepresented one in our study. However, organic and environmental sustainable UPA should also be set on the political agenda since it is connected to multidimensional co-benefits, such as support of the local economy, social inclusion, and biodiversity [81]. Residents value the taste and smell of local organic food, criticizing the conventional agri-food system as being non-sustainable [82]. Arrobas et al. (2017) recommend that organic farming should be the preferable management practice since it can reduce environmental risks for the city environment and produces edible plants with low content of trace metals due to the absence of pesticides and a severely reduced use of fertilizers [80]. However, the healthy status of the plants might also be due to reduced traffic and the low industrialization rate in the case study cities [80]. The findings of the review suggest that more research on organic UPA is needed, including its chances, opportunities, and challenges of implementation on a broader scale. 


\subsubsection{Resource Efficiency}

In light of resource scarcity and the challenge to feed the increasing urban population, the current modes of conventional food production are requested to reduce the urban footprint. To use resources efficiently and to maintain a healthy ecosystem there is a need to adapt cyclical urban metabolism [83]. In this regard NbS is supposed to be energy and resource-efficient [18].

The potential of UPA to contribute to resource-efficient food production was investigated by 14 papers placing this challenge into the center of the ten challenges. The focus of this challenge is in particular on vacant spaces and rooftop gardens. Vacant spaces can be used to increase energy self-sufficiency by bioenergy production [84,85] without threatening food security [84]. To establish synergies between energy efficiency and food production fully, integrated rooftop greenhouses can be used to exchange $\mathrm{CO}_{2}$, rainwater and heat between the building itself and its connected rooftop greenhouse [86]. To get a full picture of the metabolism of UPA from production to consumption, life-cycle assessments of rooftop gardens showed that environmental and economic impacts differ between cultivation techniques such as nutrient film technique vs. floating vs. soil [87], rooftop garden vs. industrial greenhouse [88] or open-air rooftop vs. rooftop greenhouses [89]. Food production, such as by rooftop gardens, can support sustainable distribution by reducing food miles and providing environmental benefits along the life cycle such as reduced product loss during distribution and in the end limiting the amount of food waste [88]. Innovative farm management strategies can support the closing of cycles, as well. The production of algae promotes the re-use of nutrients and fixates carbon. Algae can be grown on water as an alternative option when space is limited in coastal and delta cities [39]. An urban stormwater farm in Melbourne (Australia) harvested stormwater from a 300 ha residential, densely built-up area to irrigate 20 ha of orchard and permaculture gardens and 2 ha allotment gardens [90]. Buildings' rooftops can also be used for water harvesting. By modeling the irrigation potential of 2,631 fruits and vegetables gardens in Rome (Italy), results indicate that $19 \%$ and $33 \%$ of the study sites achieve water self-sufficiency depending on the irrigation efficiency [91]. Whether residents choose alternative watering sources for their gardens depends, according to a study from a Mediterranean region, on socio-demographic drivers such as unemployment, retirement and education level [92]. All in all, all reviewed examples showed a range of opportunities for resource-efficient UPA forms. However, it should be mentioned that the cases presented mostly address single case studies, models and experiments. Further research in this regard should prove how these cases can be implemented on a larger scale considering planning realities and local conditions.

\subsubsection{Urban Renewal and Regeneration}

Urban regeneration through $\mathrm{NbS}$ is one of seven actions which are promoted by the European Commission suggesting among other things the revitalization of vacant space through community gardens and urban farms [18].

With 14 papers this challenge is placed, like challenge 5 (see Section 3.2.5), in the center of the challenges investigated. In the focus of the papers are urban regeneration actions through requalifying urban vacant spaces such as through community gardens $[93,94]$ and urban horticulture such as the implementation of gardens in public spaces, an abandoned ex-military barrack or in the neighborhood [95]. A case study in New York City (USA) found that in Manhattan 18\% of vacant spaces are indeed used for community gardening [96]. Besides community gardens, rooftop farming can also contribute to urban regeneration $[97,98]$. Regardless of the type of UPA, these studies suggest that UPA promotes urban regeneration processes by improving the city's image [95], supporting local food supply [95,97], promoting urban biodiversity and increasing economic benefits for low-income residents by saving food costs [99]. Furthermore, UPA is perceived as being more attractive, for example community gardens instead of vacant land plots [93]. In particular, the social benefits of urban regeneration processes are emphasized in the studies. Urban gardening initiatives on abandoned land promote social interaction $[95,99,100]$ and support residents after disasters, such as Hurricane Katrina in New Orleans by fostering self-governance and reclaiming public space and identity [101]. However, 
due to limited spaces in cities vacant spaces can also be welcome options for urban development and residents need public support to access this land for gardening [94]. Temporary community gardening initiatives are one option for using vacant spaces and profiting from urban regeneration processes [100]. Finally, it must be concluded that using UPA as NbS for urban regeneration must be implemented with caution. Depending on the location and its former function the area can be contaminated with trace metal which might harm food quality and human health [102] (see also Section 4.2).

\subsubsection{Land Management and Governance}

To successfully implement $\mathrm{NbS}$ there is the need for supporting institutional frameworks and governance structures, such as green space management $[18,21]$. Such a challenge has often been raised in this review and, according to the number of papers, it is the second most important one.

Even though the focus of the papers generally dealing with $\mathrm{NbS}$ is on green infrastructure planning $[19,21,27]$, only a few papers in this review take-up explicit management implications for UPA relating to green infrastructure planning. A German study found that low-intensity farmland has great potential to contribute to the connectivity of urban green infrastructure, even more than forests at the city level [103]. However, urban forest is a crucial provider of ecosystem services, such as microclimate regulation and recreation [104]. Their contribution to urban food supply is, according to our review, mostly neglected and only three papers focus on edible forests [105-107]. In terms of management implications, one paper addresses the potentials of urban forests for fruit production and part of the urban edible landscape which should be fostered by urban planning [107]. Thus, according to their case study in Seattle (USA), they found that city regulations forbid the planting of certain fruiting varieties such as of cherry or apple [107]. The fact that the mainstreaming of UPA in the urban planning process needs institutional support was emphasized by a range of papers $[40,108,109]$. Studies suggest it needs broad coalitions between different actors to place UPA on the political agenda $[110,111]$ and to implement UPA in the urban landscape such as through sharing private green spaces for urban food production under the principle of the sharing economy [112]. Another conclusion drawn from several papers is that emphasizing the multidimensional benefits derived from UPA sharpens the perception by authorities that UPA is a major pillar for sustainable urbanization $[113,114]$. One factor constraining UPA is the lack of or only temporary access to land $[111,115,116]$, which is often under threat due to competition with other land uses [117]. To secure areas of high agricultural productivity in UPA areas, it needs an optimization and a targeted planning of urban development and its configuration [118,119].

To secure a high productivity of land and healthy food supply another line of papers suggest that an integrative management of UPA needs to test the soil conditions before implementing UPA, thus taking into account chemical and physical characteristics [120], the site history and atmospheric deposition trends [121] feeding into a site-specific risk assessment [122], which includes a human health risk assessment as well [123]. Further constraints and drivers of UPA implementation going beyond this challenge are presented in Section 3.3.1.

\subsubsection{Public Health}

Ten papers of the review reflect positive impacts of UPA on public health and quality of life, giving them a ranking of seventh place according to the number of papers. The fact that urban green spaces contribute significantly to mental and physical health as a major benefit from $\mathrm{NbS}$ is widely accepted $[19,33]$. The papers identified in this challenge solely study health implications with community gardens (8 papers, e.g., [124-126]) and allotments (2 papers, [127,128]. Through surveys and interviews self-related health status and perceived benefits from gardening were assessed, e.g., $[124,127,128]$. All studies concluded that residents experience health benefits through urban gardening resulting from social interactions in particular [124,126-129]. Especially for vulnerable population groups such as the elderly [130], residents recovering from natural disasters [131] or patience in hospitals [124], urban gardening can be considered a restorative greening activity supporting learning and empowerment. Health benefits occur as well through promoting the 
intake of healthy food [126,132]. Comparing the self-reported health impacts between gardener and non-gardener, a study found that gardeners were perceived to generally have better health conditions than non-gardeners [127]. However, when it comes to physical assessments, which analyze the BMI between gardeners and non-gardeners, studies are inconclusive reporting no differences between gardeners and non-gardeners [127]. Another study found significantly lower BMIs of community gardeners compared to their neighbors not involved in community gardening [129]. To get a broader and valid picture of health impacts by UPA future studies should not only focus on urban gardening but also on other forms of UPA such as related to urban farming. These studies should also go beyond self-reported health benefits and undertake interdisciplinary research together with life sciences.

\subsubsection{Social Cohesion, Social Justice, Participation/Civic Engagement}

As demonstrated in Section 3.2.8, well-being through gardening results among other things from social interactions and integration. 21 papers take a deeper look at the role of UPA contributing to social cohesion, social justice, and civic engagement, resulting in the fourth most investigated challenge in this review. In general, the strengthening of community cohesion and involvement of society in urban development is a main aim of $\mathrm{NbS}$ to support urban residents re-connecting with nature [18].

Municipalities play a crucial role in supporting UPA by providing access to land and legal permissions $[133,134]$. However, the initiators of UPA initiatives such as community gardens are mostly driven by NGOs or civic groups [133]. The drivers for civic agriculture can differ between the types of UPA: community farms are argued to target civic participation and food supply for people with low income. In contrast, commercial farms focus on financial sustainability [15]. The motivations for engaging in UPA differ among the residents as well. Studies showed that reasons for urban gardening are environmental concerns for educated residents. In contrast, for low-income and unemployed gardeners urban gardens can support the access to food and supplement the family budget [134]. In this regard, UPA gains importance for poor people and people out of work in particular in light of current financial and economic crisis, such as shown in the example of Lisbon (Portugal) [135] (see also Section 3.2.2 (challenge 2)). In fact, residents doing urban gardening experience a sense of belonging, empowerment and environmental awareness [135-139]. These findings can be interpreted in light of current challenges connected with the resistance of neoliberal urbanization and the demand of residents to reclaim public space and self-governance, to experience solidarity and use UPA as a form of emerging commons [140]. The multidimensional benefits from UPA also offer the opportunity for social cohesion, since actors are forced to be confronted with a plurality of various perspectives which are the basis for a democratic society [141]. In this regard, it must also be mentioned that social justice of UPA can be harmed such as due to race- and class-based disparities among UPA practitioners [142,143]. In the end, it can be concluded, that for a successful civic agriculture there is no strategy which fits all cities but the various planning, economic and cultural framework conditions of each city UPA is embedded $[133,144]$ as well as the socio-economic and cultural background of the residents and their position within the community need to be considered [134,145].

\subsubsection{Economic Growth}

$\mathrm{NbS}$ can be considered a flagship term which supports the development of innovations, create jobs and fosters the green economy by incorporating natural capital in integrative policies and planning $[18,22]$.

The economic benefits of UPA are reflected by 12 papers showing that current research dealing with UPA considered more often environmental (e.g., biodiversity) or social aspects such as social cohesion or food security. In fact, UPA projects combining economic with social and ecological goals can gain higher acceptance by urban residents than professional UPA driven by technology [146]. A study suggests further that: “( . . ) maximizing urban agriculture's economic impacts can take the form of enabling broad participation through human capital development, grower support programs and securing land tenure for gardens and farms." [147], p. 13. A study in Germany found that UPA projects 
do not focus on only one business model, but that direct marketing is combined with participatory farming along increasing urbanity [148]. Such benefits can be fostered by innovative forms of UPA such as ZFarming (Zero-Acreage Farming including indoor farming, rooftop greenhouses, open rooftop farms) [149-151] or urban aquaponics [152].

Besides the potentials of UPA contributing to economic growth and innovation, economic implications on UPA arise through responses by residents of neo-liberalization and economic crisis $[149,153]$. The increasing social awareness of food and the negative impacts induced by industrialized agriculture is highly political and can be considered as a gateway to general criticisms of capitalism harming natural capital and social justice [154]. Due to these critical views of the current economic system, UPA is attracting renewed attention as a major space to "engage the politics of food" [154], p. 351

\subsection{Implementation of UPA as Nature-Based Solution and Its Co-Benefits}

By taking into account UPA as systemic NbS, we identified important framework conditions influencing the implementation of UPA and potential co-benefits. The drivers and constraints as supportive framework conditions for UPA, related to steering instruments, multidimensional co-benefits and relevant actors important for implementation as well as affected by UPA identified during the review, can be considered as system elements of UPA. The detailed findings of the system elements can be structured by categories (e.g., social, ecological, economic, spatial, and technological drivers) and their indicators. In general, indicators are useful to evaluate the effectiveness of $\mathrm{NbS}$ and make their effects visible [19]. This section presents the system elements and its categories. The complete list with the complemented indicators per category can be found in Supplementary Material S3 for factors influencing UPA implementation and Supplementary Material S4 displaying UPA co-benefits and affected actors.

\subsubsection{Drivers and Constraints of UPA Implementation}

The following section deals with factors influencing the implementation of UPA based on our review. We distinguish between constraints and drivers which are of social, institutional, economic, ecological, spatial and technical nature and identified important instruments supporting UPA implementation.

Figure 4 summarizes the categories of our findings with regard to UPA implementation. The total number of drivers cited in the review $(n=442)$ outnumbers the amount of constraints $(n=296)$ by far, underlining the fact that different forms of UPA have, generally speaking, a rather positive image. Social drivers $(n=225)$ clearly dominate the other categories. "Community participation and building" with 36 citations is considered to be the major social driver in our review ( $16 \%$ out of all social drivers), followed by "access to food in qualitative terms" (13\%), including for instance access to fresh and healthy food, e.g., [54,58]. Surprisingly, the multifunctionality of UPA, which is seen in our paper as a major benefit of UPA, finds only weak consent in the review literature regarding social drivers (9\%). This fact underlines the still underestimated multifunctional potential of UPA in empirical case studies. Nevertheless, one has to consider that some papers address different functions of UPA, e.g., [113,133], but do not explicitly mention its multifunctional character. The second-most cited category refers to institutional drivers of UPA implementation $(n=81)$. In this case, "policy regulations supporting UPA" $(41 \%)$ is seen as the major institutional driver, according to the reviewed literature. It includes laws and regulations mainly introduced or amended by the city government (see also Section 3.3.2). "Bottom-up policy-making" is also considered as an important driver in this category $(22 \%)$, in which citizens are actively involved in shaping the local policy agenda in favor for UPA, e.g., [40,155]. In contrast, "top-down policy-making" with clear rules in allotment gardens is regarded as a minor institutional driver within the review and is cited only once [111]. The main driver for UPA implementation within the economic category $(n=69)$ refers to "resources available for UPA" (38\%), including funding for projects, employment opportunities or knowledge on UPA, 
e.g., $[84,112,156]$. Conversely, a minor economic driver includes the "proximity of the supply market" for food products [105] (1\% out of all economic drivers). Ecological drivers are cited 33 times in total. In this category "nature protection", including preserving and enhancing biodiversity [72], for instance, plays a major role in the review literature (64\%), while "counteracting environmental pollution" through UPA (18\%) is perceived as a minor ecological driver for UPA implementation. Spatial and technical drivers in general are less often cited than the other drivers within the categories mentioned above. Regarding spatial drivers, "securing space for UPA" is of major importance (33\%), which can be seen as a consequence of limited space for UPA due to increasing urbanization [157]. In contrast, a "low demand for new residential areas", is of minor importance regarding this category $(4 \%)$, further underlining the urbanization pressure inherent in many case study cities. The main driver in the technical category $(\mathrm{n}=10)$ refers to "efficient management methods" $(50 \%)$, such as recycling, e.g., [50] or the cultivation of space-efficient crops, e.g., [158], whereas "regular maintenance of UPA areas" $(10 \%)$ appears to be of minor importance in the review.

Regarding the constraints of UPA implementation, most can be found in the institutional category $(\mathrm{n}=100)$. The most frequently cited indicator here is the "lack of governmental support" $(19 \%)$, which puts UPA low on the local policy agenda, e.g., [95,159]. In contrast, "unclear ownerships" (3\%) of land or "unclear responsibilities in the city government" $(1 \%)$ appear to be a minor constraint for the implementation of UPA in this category. The second-most cited constraints refer to the social dimension $(n=72)$. In this category, a "lack of community support" $(n=38 \%)$ is the most striking constraint for the implementation of UPA. This constraint includes a lack of citizens' motivation [43], negative perceptions of UPA forms [77], lack of trust [82], or even vandalism [160]. "Constraining food consumption patterns" (3\%), such as the consumption of food products from globalized industrial agriculture, e.g., [117], do not play a highly restricting role for UPA implementation in the review. Economic constraints make up the third-most cited category $(n=59)$. In this case, "costs related to UPA", such as the costs for labor, energy, management, and construction of UPA activities, e.g., [85,97], as well as limited resources referring to manpower, finances, or time, e.g., [58,61], seem to be a major concern for UPA implementation in this category ( $31 \%$ respectively). In contrast, the "lack of an UPA business model" is considered to be a minor economic constraint in the review literature $(2 \%)$. Ecological constraints, totaling 34 citations of indicators, mostly referring to soil contamination $(32 \%)$ through the use of pesticides, e.g., [45], which may affect the practice of UPA. Conversely, "flood risk" (3\%) or the "overabundance of animal manure" (3\%) affecting UPA is not seen as a major limiting ecological factor for its implementation. Analogue to the drivers, spatial and technical constraints play a minor role in comparison to the other categories mentioned above. Spatial constraints ( $\mathrm{n}=14)$, largely refer to "limited space for UPA" $(71 \%)$ e.g., through land fragmentation derived from urbanization [157], which in turn results in long waiting lists for UPA areas [159], followed by "lacking physical accessibility of land for users" for example due to long distances to UPA areas (29\%) [143]. Regarding technical constraints $(n=17)$, infrastructural constraints, including, for instance the weight of rooftop gardens, which can be too high for construction [89], make up the main technical constraint for UPA implementation (47\%), while "lack of technological knowledge" (18\%) plays a minor role.

Overall, one has to consider that even though some drivers and constraints have been mentioned only once or twice, this does not mean that they are not important for the implementation of different forms of UPA. On the contrary, they might even signalize a research gap, which has to be addressed. Thus, a next step should be to elaborate on the indicators further by conducting a prioritization method, such as the multi-criteria analysis based on stakeholder preferences in specific case studies [161] (see also Section 4.1.4.).

\subsubsection{Instruments Supporting UPA Implementation}

The instruments promoting the implementation of UPA in the review are manifold. Most of them refer to financial aspects and incentives (29\%), including, for example subsidized start-up costs for new gardeners, e.g., [44], or tax breaks for rooftop farmers, e.g., [110,162]. Laws and regulations promoting 
UPA are often mentioned as important instruments in our review, as well (27\%). They can be either formal, such as the Community Empowerment Act in Glasgow (Scotland), which empowers citizens to receive land for local food cultivation [144] or informal in the form of urban visioning documents, such as the South Hyllie Master plan in Malmö, Sweden, which focuses on "farming" and "culture" as key action fields for UPA [133]. Informational instruments play also an important role for the implementation of UPA. These include training and education (17\%) in the form of e.g., workshops on urban gardening [95,109], public relations [61,160] (10\%) (e.g., websites or newspaper articles on UPA) or the creation of respective networks, exchanging information and knowledge on UPA [149] (8\%). Further instruments mentioned in the review refer to the monitoring of UPA areas ( $8 \%$ ), including land inventories of potential UPA spaces [163], modeling approaches [75], or holistic risk assessments [40] in order to observe multidimensional opportunities and threats of UPA quantitatively.

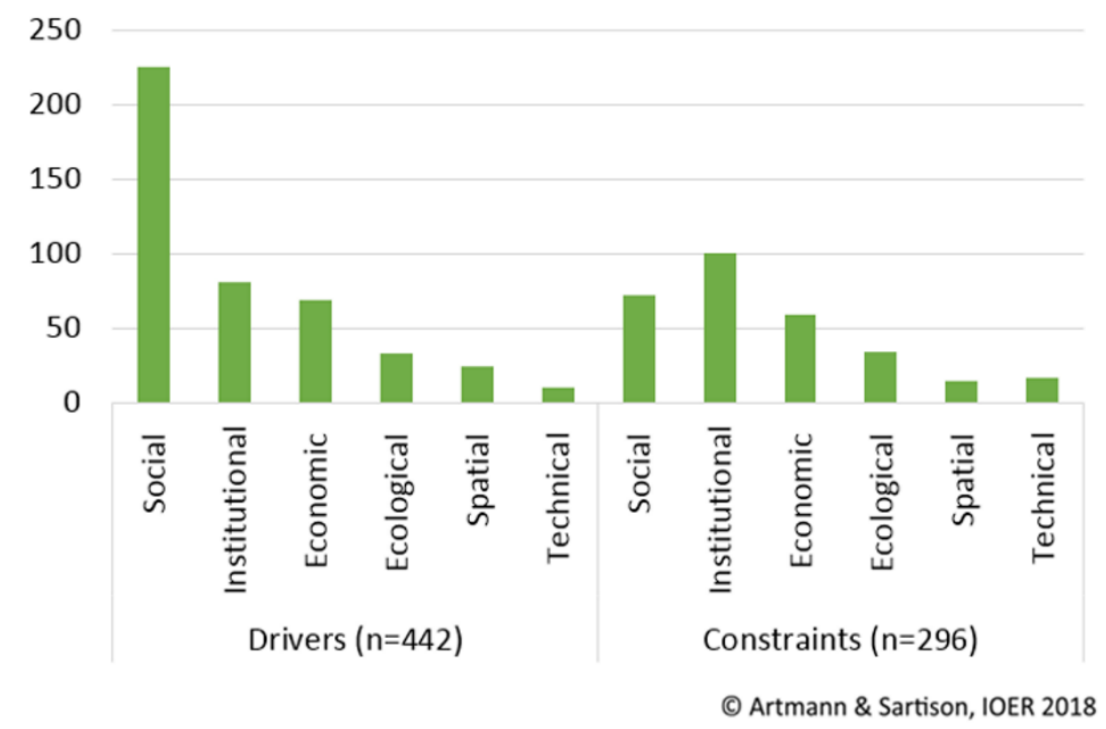

Figure 4. Drivers and constraints of UPA implementation per category ( $\mathrm{n}$ total $=738$ ).

\subsubsection{Actors Relevant for UPA Implementation}

The actor constellation relevant for UPA implementation ranges from macro over meso to micro scale.

The macro scale ranges from the integration of UPA into global policies $(n=1)$ over European government level (European Union) $(\mathrm{n}=2)$ over national level (national government and national informal networks) $(n=5)$ to the regional government level $(n=16)$, while the latter is predominant in this scale. The meso scale includes mainly the city government $(n=73)$ with its different departments, such as urban planning [164], environmental [96], or health departments [100], while the micro scale clearly and obviously shows the highest number and diversity of actors $(n=263)$. Non-governmental organizations (NGOs) $(n=43)$, residents $(n=41)$, (urban) farmers $(n=30)$, gardeners $(n=27)$ as well as vulnerable population groups, including children and youth, pensioners, immigrants, people of low income, or ex-criminals $(n=26)$ make up the highest share within the review literature. Further important actors are local and/or social companies $(n=20)$, researchers $(n=16)$, architects and planners $(n=12)$, volunteers $(n=12)$, activists $(n=11)$, consumers $(n=6)$, donors $(n=4)$, investors $(n=3)$, artists $(n=2)$, therapeutical clinics $(n=2)$, real-estate agencies $(n=2)$, food policy councils $(\mathrm{n}=2)$, teachers $(\mathrm{n}=2)$, and (local) media $(\mathrm{n}=2)$. 


\subsection{Co-Benefits of UPA}

\subsubsection{Ecosystem Services and Multifunctional Benefits by UPA}

UPA can supply multiple forms of ecosystem services and multifunctional social, economic, and ecological impacts, which can be seen as UPA co-benefits. Figure 5 summarizes our results related to ecosystem services provided by UPA. The most often cited ecosystem services are of cultural nature $(\mathrm{n}=111)$. In this case, "recreation and mental and physical health" are of major priority $(33 \%)$, followed by "education and learning" $(27 \%)$ and "nature experience" $(17 \%)$. UPA serving as a "tourism" opportunity plays a minor role in the review (9\%). Second-most cited ecosystem services classification is the provisional one $(n=97)$, which focuses mainly on food supply. Here, we distinguish between "food supply-quantity" $(60 \%)$, including local food supply in general, e.g., $[97,109]$ and "food supply-quality", referring to for instance fresh, healthy, and/or organic food (34\%), e.g., [125,160]. Other provisional ecosystem services include "medicinal resources" (5\%) [47] and the "supply of raw materials" in general (1\%) [85]. Regulating ecosystem services $(n=66)$ include particularly the "regulation of local climate and air quality" (27\%) [46], "run-off mitigation" (20\%) [52], or "maintenance of soil fertility" (18\%) [165], while "noise reduction" [166] or "waste-water treatment" [39] plays a minor role as do co-benefits and regulating ecosystem services ( $2 \%$ respectively).

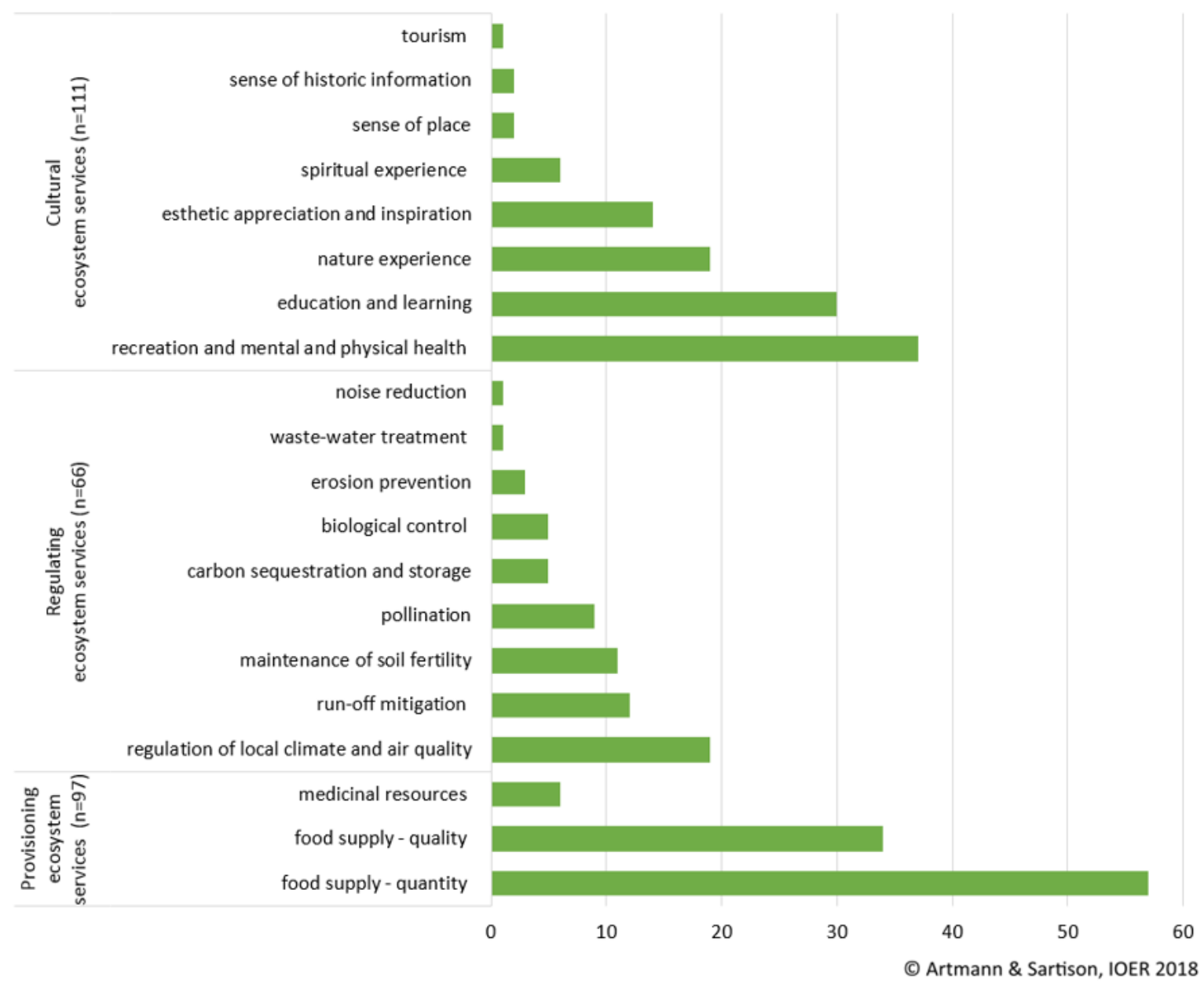

Figure 5. Supply of ecosystem services as UPA co-benefits $(n=274)$.

Besides providing ecosystem services as co-benefits, the review found that UPA stands out for its multifunctionality, encompassing social $(n=162)$, economic $(n=72)$ and ecological categories $(n=72)$. An overview of all multifunctional co-benefits and ecosystems services is listed in 
Supplementary Material S4. Regarding multifunctional co-benefits, social impacts are predominant in the review literature and "community-building and participation" with 59 citations is, similar to the social drivers (see Section 3.3.1), by far the most prominent indicator in the whole review (19\% of all co-benefits, $36 \%$ of all social co-benefits). Community-building and participation include, social integration [50,60], citizen engagement [81,133], stakeholder participation [97,167], or the sharing of food and other resources [15]. Not as striking but also of main importance in the review are the social co-benefits of "environmental awareness-raising and education" (17\%), for example through community garden events, [56] or workshops [97], as well as the contribution to "public health" $(17 \%)$ [50]. In contrast, a positive media awareness of UPA, e.g., [159], plays only a minor role, according to the review literature (1\%).

Both, economic and ecological co-benefits have been cited 72 times equally in the review. Considering economic co-benefits, "resource savings" in form of costs [168], energy [169], or waste [88], is a major indicator within the economic category (42\%). It is closely followed by "income and job creation" (35\%) [133,167] and "local market benefits" (24\%), such as local cycling of money [147] or fostering local competition [113]. Ecological co-benefits mainly refer to "habitat provision and biodiversity" [65,170] (32\%) as well as to the "reduction of environmental pollution" sources (32\%) such as $\mathrm{N}_{2} \mathrm{O}$ by the use of soilless crops [45]. Conversely, "avoided land transformation" (4\%) [169], for example, is of minor importance within the ecological category of co-benefits.

\subsubsection{Actors Affected by UPA}

In contrast to UPA implementation, the macro scale is not affected by the impacts of UPA, according to the review. The meso scale, incorporating the local government with its different departments and the council, is affected in 18 cases e.g., through further city income generation [15] or a better city image [113] thanks to UPA. Similar to the actors relevant for UPA implementation, the micro scale has the highest number and diversity of actors within the review $(n=146)$ and includes residents $(n=48)$, vulnerable population groups (including children and youth, pensioners, immigrants, people of low income, unemployed people, homeless people, handicapped people, clinic patients $(\mathrm{n}=28)$, (urban) farmers $(n=21)$, gardeners $(n=15)$, consumers $(n=7)$, NGOs $(n=4)$, researchers $(n=4)$, volunteers $(n=4)$, activists $(n=3)$, local and/or social companies $(n=3)$, tourists $(n=3)$, real-estate agencies $(n=2)$, investors $(n=2)$, artists $(n=1)$, and journalists $(n=1)$.

\section{Discussion}

\section{1. (Peri-)Urban Agriculture as Nature-Based Solution-An Assessment Framework}

As shown in the previous sections, UPA contributes to a range of societal challenges supplying multidimensional co-benefits. Therefore, we suggest, that UPA can be considered as an urban $\mathrm{NbS}$. According to Eggermont et al. (2015), there are three types of NbS: (1) NbS with no or minimal interventions in the ecosystem, (2) NbS that seek to advance multifunctional and sustainable ecosystems and landscapes and (3) solutions designing and managing new ecosystems such as greening grey infrastructure [22]. Innovative approaches for multifunctional agricultural landscapes, aiming for natural systems, can be considered as the second type of $\mathrm{NbS}$ [22]. However, since agriculture within cities can be implemented in and on buildings as well [151], UPA can also fall into the third NbS type and UPA can be considered as a hybrid solution for sustainable urban development.

To implement innovative NbS there is the need of integrative evaluations [161], which can be supported by indicators [19]. Raymond et al. (2017) developed a general seven-step framework for $\mathrm{NbS}$ assessment which has been adapted and specified for UPA in this study [21]. To foster UPA as NbS we suggest, based on the review results, that three steps should be considered for an integrative UPA assessment: 1) vision definition, 2) implementation efficiency, and 3) impact efficiency (see Figure 6). Efficiency is understood as the degree of UPA as NbS contributing to a specific societal challenge $\left(C_{x}\right.$, $\mathrm{C}_{\mathrm{y}}, \mathrm{C}_{\mathrm{z}}$ ) (see pillar 1). 


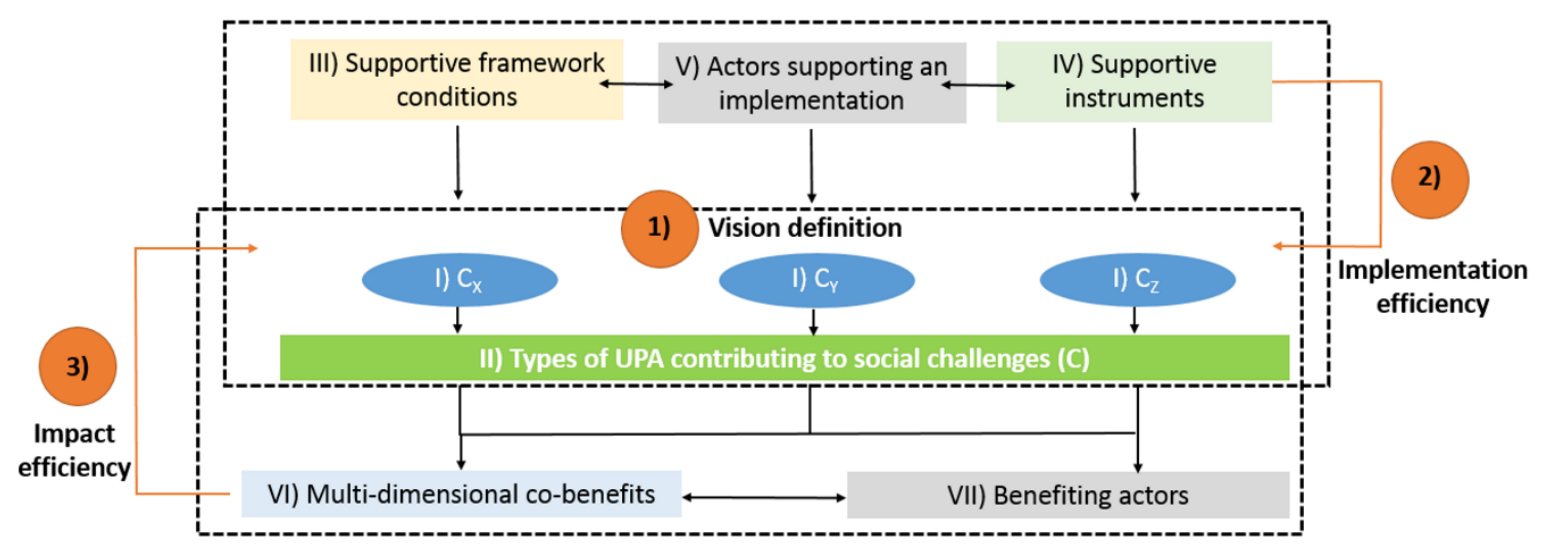

Figure 6. Assessment framework for UPA as NbS.

\subsubsection{Vision Definition}

To foster a successful NbS implementation and reduce the complexity of problems, there is a strong need to define clear visions and identify the key challenge areas the solution should address [21,22,171]. Our review showed that UPA has the potential to at least address ten various challenges (although we argue that the list of challenges should not be regarded as complete). In fact, assessing the success of UPA should take into account its multisectoral nature [158]. The challenges then can act as guiding visions UPA should contribute to. However, the significance of challenges might differ between local conditions and actors in charge that could make a selection and prioritization of challenges necessary. While in shrinking cities the revitalization of vacant spaces through UPA might be a crucial field of action [172], in growing cities the implementation of UPA into the built infrastructure can present a pressing need to reduce heat island effect and flooding while keeping the city compact [173]. Another reason to select only a few challenges might be the lack of resources to implement and monitor $\mathrm{NbS}[19,21]$. Indeed, in some papers more UPA monitoring was recommended such as related to pesticide pollution [174], food safety [95], and soil quality [120]. All in all, UPA should not only focus on a single challenge. In general, agriculture can be considered as being sustainable when being multifunctional and offering additional functions to food production in environmental, social, and economic dimensions [36]. From the 150 papers analyzed in depth, 37\% of the papers focus on two, $6 \%$ on three challenges (6\%) (see Supplementary Material S2). The most investigated additional challenge is related to social cohesion (challenge 9 ) which is promoted by UPA in the course of urban renewal and regeneration (challenge 6, e.g., [95,97,99]).

Besides selecting and/or prioritizing the challenges, there is the need to identify which types of UPA can contribute to these challenges. Thus, our review underlines that UPA must be understood as a mosaic of sub-solutions such as urban farms, community gardens, or indoor farming. So far, the focus of current research is clearly on community gardens $(n=58)$, followed by residential gardens/backyards $(n=24)$, and rooftop gardens and rooftop greenhouses $(n=23)$. Less often investigated were, for instance organic farms $(n=1)[106]$ or orchards $(n=2)[72,163]$. For mapping different forms of UPA, Google Earth and web-mapping services can be used as demonstrated on the residential garden, community garden, urban farm, institutional garden, and illegal garden [175]. During the analysis of the reviewed papers it became evident that the categorization of the different types of UPA could not be done in a stringent manner since the terminology of the papers differed, for instance between a spatial perspective where UPA was conducted (e.g., on roof tops, peri-urban land, indoor), actor perspective (e.g., family farm, community rooftop farming), or production perspective (e.g., aquaponics, professional UPA, hobby farm). The analysis showed further that so far a strategic comparison of the different types of UPA is missing. More research is needed to categorize the different forms of UPA and to identify their advantages and disadvantages contributing to challenges 
of urbanization. The categorization of UPA should also reflect a technological perspective of UPA to identify any benefits between more technical types of UPA (e.g., hydroponics [156]) and more natural types of UPA (e.g., organic garden [137]). In general, there is the demand to demonstrate the effectiveness of $\mathrm{NbS}$ compared to technology-based solutions such as targeting climate change adaptation and mitigation [25]. The assessment framework developed in this study can be used for such an integrative assessment related to UPA.

\subsubsection{Implementation Efficiency}

The implementation of UPA can be influenced by a range of drivers and constraints such as institutional, economic, social, spatial, or technical ones (see Section 3.3). Thus, when deciding on the types of UPA it should be checked if and with which efforts they can be implemented. For instance, the acceptance between UPA might differ depending on the degree of their naturalness. The implementation of ZFarming can be constrained by the perceived risks associated with being 'unnatural', health hazards, rejection of animal in cities, or as being too expensive [164]. In general, the implementation of innovative forms of UPA need a strong political support to share any risks and provide supportive regulations [151,152]. Thus, when assessing the implementation efficiency of UPA also supporting actors and instruments should be taken into account promoting strategic green infrastructure planning (see Supplementary Material S3). In general, NbS needs innovative forms of stakeholder engagement and any adaptions of policies, planning and legislation for supporting $\mathrm{NbS}$ need to be identified [18,21]. That actors support is of crucial importance for UPA implementation can be assumed by the fact that in particular community support as a social driver and lack of governmental support as an institutional constraint are the most mentioned indicators in the reviewed papers (see Section 3.3.1). The majority of papers of the review suggest that UPA should be considered as a bottom-up activity rather than a top-down urban planning approach (e.g., [95,117,141]). At the same time, professional coordination is important to compensate short-term commitment by residents [176], suggesting that a multi-scale governance enables UPA implementation [133]. To avoid residents rejecting urban garden projects, an early involvement of relevant actors and communication plans for participatory and multi-stakeholder dialogues are recommended [95,97]. That bottom-up initiatives are in the focus of the majority of reviewed papers might result from the fact that most of the case studies refer to urban gardening projects rather than urban farming (see Section 4.1.1). If there are differences in the success of top-down vs. bottom-up initiatives between different forms of UPA further research is required.

\subsubsection{Impact Efficiency}

The systemic nature of $\mathrm{NbS}$ arises through their supply of social, economic, and ecological co-benefits which need to be assessed along the implementation process $[18,21]$. Our review showed that UPA provides a range of ecosystem services as well as co-benefits which are not directly derived from the ecosystem (e.g., jobs, support of environmental behavior, see Section 3.4). Thus, in our assessment framework we suggest considering the multifunctionality of UPA, as well as ecosystem services supplied by UPA. Combining the assessment of multifunctional agriculture as farm-centered approach with ecosystem services provided by agriculture as service-centered approach, we can operationalize a sustainable agricultural management [36]. In the assessment we suggest embedding the ecosystem services of UPA into the multifunctional agricultural approach by applying a trinomial classification of ecosystem services reflecting productive services as economic, regulatory services as ecological and cultural services as societal pillars. By doing so a direct link between the concepts of ecosystem services and sustainability can be made visible [37]. In our framework biodiversity can then be considered as an ecological impact by UPA. Interestingly, the review showed that although the major focus of the papers is on challenge 3 (biodiversity and ecosystem services), this challenge is only considered by two papers as an additional challenge $[105,135]$. This might be due to the fact that the concept of ecosystem services is considered to be an integrative, holistic approach, which makes the 
multiple benefits humans receive from the ecosystems visible [177] and thus, making an explicit focus to further challenges related to UPA unnecessary.

The review showed further that a range of actors is benefitting from UPA and its related ecosystem services and multifunctional benefits (see Supplementary Material S4). This fact is in our assessment framework respected by not only considering different actors engaged in UPA (see Section 4.1.2) but also reflects who is indeed benefiting from UPA (see Supplementary Material S4). By doing so, the framework allows to cross-check if vulnerable and disadvantaged population groups have access to the positive impacts by UPA as well and to avoid any race- and class-based disparities among UPA practitioners [142].

\subsubsection{Possibilities for Applying the Assessment Framework}

The assessment framework introduced in this study suggests that UPA can target a range of visions which can be achieved by various forms of UPA. UPA realization is driven by multifaceted framework conditions as well as benefits and risks that need to be addressed. To handle this complexity the framework can be approached by applying a multicriteria analyses (MCA). MCA can support an integrated valuation of $\mathrm{NbS}$ by identifying appropriate strategies for water pollution control and their multidimensional benefits taking into account preferences by different stakeholders [161]. In our framework, MCA can be used to prioritize the challenges and types of UPA contributing to them. The drivers and constraints of realization and multidimensional co-benefits can be used as indicators to identify implementation (see Supplementary Material S3) and impact efficiency (see Supplementary Material S4). Indicators are operative tools to monitor and characterize NbS [19,21]. The indicators are embedded then in the various system elements I-VII (see Figure 6) framing the UPA system as $\mathrm{NbS}$. By doing so the framework reflects that $\mathrm{NbS}$ stand out for their systemic approach to manage and solve challenges [27].

For the assessment, a mix of methods can be used depending on the challenges and types of UPA to be assessed such as shown in the reviewed papers. For analyzing enabling factors of UPA stakeholder interviews [111] and planning analysis can be conducted [110]. To visualize multiple ecosystems services provided by UPA, remote sensing [165], models such as inVest analyzing the pollination potentials [75], plant inventories and regression modelling [64], or interviews with gardeners [61] can be conducted, to name only a few methods. For the integrative assessment an inter- and transdisciplinary team is recommended.

\subsection{Risks and Ecosystem Disservices Related with UPA}

Despite UPA's potential as being a NbS, and the fact that the majority of the papers in our review hold clearly positive perspectives on UPA (see Section 3.1.3), there is the need not to romanticize UPA but to reflect also its potential risks and negative impacts [14] such as those related to ecosystem disservices [178]. Papers focusing on threats by UPA to the respective challenges (see group of papers 1a and $1 \mathrm{~b}$, Section 3.1.3) mention, for instance, that benefits such as reduced food miles can be constrained by high energy demand [179] and inefficient water input [92]. In the review, papers critically reflect in particular on potential risks by UPA related with public health (challenge 8). Papers deal with contaminations concerning, for instance, soil health [180-182] or crops [166,183]. Also potential risks of contamination through irrigation is considered $[184,185]$. Both papers found that irrigation such as through stormwater [184] does not harm food security for human health [185]. Studies on ecosystem disservices dealing with potential health risks through soil and crop pollution have differing findings. Results on contamination of soil show that risks for human health can arise through soils contaminated with $\mathrm{Pb}[180,181]$ or Cr, As, and Cd [182]. However, not all sites investigated by the studies exceed the limits of contamination. Studies suggest that the level of risk strongly depends on the sites, their land use history and impact by anthropogenic activities [180,181]. Also studies dealing with crop pollutions found that health risks differ between trace elements, management practice and types of crops cultivated [166]. Such as found in studies on soil pollution, health risks through crops can occur 
through $\mathrm{Pb}[166]$. However, other studies found that $\mathrm{Pb}$ was below the limits $[183,186,187]$ and the products can be consumed without risks to human health. To get clear results, there is a strong need for site-specific and detailed risk assessment and clear soil trace metal guideline by policy [182,188]. Consumers need to wash the food properly and avoid soil ingestion to reduce potential risks [187].

Like the minor focus of papers on threats related to UPA, the review shows, that papers also dealing with positive impacts by UPA (see group of papers $2 a, 2 b, 3 a, 3 b$, Section 3.1.3) clearly focus on more multifunctional co-benefits $(82 \%)$ than threats $(18 \%)$ derived from UPA. These findings underline the positive image UPA has in general. Such as the multifunctional co-benefits, threats related to UPA include social, economic and ecological categories ( $\mathrm{n}$ total $=166$ in our review).

Ecological threats are of major concern in the review $(n=33)$. "Threats to soil through UPA activities", including, for instance soil contamination through pesticide and chemical fertilizer use e.g., [77], are most often cited in this impact category (42\%). In contrast, "high electricity demand related to UPA", for example for increased lighting of plants [152], was mentioned only twice in the whole review. Negative social impacts of UPA are the second-most cited category of threats $(\mathrm{n}=24)$. In this case, "social injustice" $(38 \%)$, including race- and/or class-based disparities within UPA activities e.g., [142], is the major impact, closely followed by the ecosystem disservice "health risks of urban food provision" (33\%), e.g., due to high $\mathrm{Pb}$ concentrations in the soil of abandoned land [189]. On the contrary, "unreliable participation in UPA" activities [190] is of minor social concern within the reviewed literature $(4 \%)$. Economic threats are comparatively low in number $(n=9)$. In this category, "insecure employment opportunities" as well as "low efficiency of food self-production" pose the major threats ( $33 \%$ respectively), whereas the "low economic value of UPA areas" has a minor impact $(1 \%)$, according to the review literature. An overview of all threats is found in Supplementary Material S4.

All in all, it is argued that the concept of NbS is closely associated with natural systems agriculture contributing to multifunctional ecosystems and landscapes [9,22]. In contrast, agro-industrial techniques and conventional agriculture can have negative impacts on ecosystem services (e.g., by high input of nutrients and chemicals) [171]. Thus, due to the fact that UPA can be considered as a $\mathrm{NbS}$ there is the strong need to assess, besides UPA benefits, potential risks and ecosystem disservices related with UPA.

\section{Conclusions}

Accomplishing sustainable agriculture is a major challenge to securing the increasing food demand that is particularly connected to rapid urbanization. Our systematic literature review focusing on countries from the global north showed that UPA can support the transformation to a sustainable urban development when considered as NbS. UPA cannot only contribute to food security but also to climate chance, biodiversity and ecosystems services, sustainable agricultural, resource efficiency, urban regeneration, land management, public health, social cohesion and economic growth. We see that it is important to emphasize that the task of UPA is not only to support food self-sufficiency of cities but also the value of UPA with its multifunctional nature. Thus, there is a need to approach an ecosystem-based agriculture to avoid that agriculture remains a part of the challenge being responsible for ecosystem degradation. When properly managed, UPA helps urban residents to re-connect with nature, reclaim public spaces, recover from disasters, and gain income. UPA can incorporate various forms such as public community gardening, semi-public allotments or private farms. Our review showed that further research is necessary to reflect this wide variety of UPA, also taking into account shrinking and small cities. Such a multi-object approach can test how UPA can be up-scaled establishing an edible city. How can edible cities be implemented? Which forms of UPA should they integrate? Which multidimensional impacts can be expected? These questions shall be answered by further research. Therefore, based on the review findings, we present an integrative assessment framework for analyzing UPA as NbS. The framework can support urban stakeholders to reflect on the multisectoral nature of UPA, its impact and implementation efficiency (considering also the concepts of ecosystem 
services and green infrastructure) and thus, contributing to livable and edible cities that efficiently deal with the societal challenges of the 21st century.

Supplementary Materials: The following are available online at http://www.mdpi.com/2071-1050/10/6/ 1937/s1, Supplementary Material S1: Queries used in the database search and number of papers identified; Supplementary Material S2: Complete list of papers including challenges addressed and study focus; Supplementary Material S3: Overview of drivers and constraints, as well as actors influencing UPA implementation; Supplementary Material S4: Overview of multifunctional impacts of UPA including ecosystem services provided by UPA (co-benefits), multifunctional benefits of UPA, threats derived from UPA as well as actors affected by the impacts of UPA.

Author Contributions: M.A. developed the structure of the review. M.A. and K.S. conducted the review and wrote the manuscript.

Acknowledgments: This project is funded by the Deutsche Forschungsgemeinschaft (DFG, German Research Foundation) AR 1121/1-1. The publication of this article was funded by the Open Access Fund of the Leibniz Association and the Leibniz Institute of Ecological Urban and Regional Development (IOER). The authors would like to thank Hanna Witte, Kristin Röthig and Benjamin Zenke for contributing to the paper analysis.

Conflicts of Interest: The authors declare no conflicts of interest.

\section{References}

1. Angel, S.; Parent, J.; Civco, D.L.; Blei, A.; Potere, D. The dimensions of global urban expansion: Estimates and projections for all countries, 2000-2050. Prog. Plan. 2011, 75, 53-107. [CrossRef]

2. European Environmental Agency (EEA). Land Take. Available online: http://www.eea.europa.eu/dataand-maps / indicators/land-take-2/assessment (accessed on 24 May 2018).

3. Eigenbrod, F.; Bell, V.; Davies, H.; Heinemeyer, A.; Armsworth, P.; Gaston, K. The impact of projected increases in urbanization on ecosystem services. Proc. R. Soc. Lond. B 2011. [CrossRef] [PubMed]

4. Wilson, B.; Chakraborty, A. The environmental impacts of sprawl: Emergent themes from the past decade of planning research. Sustainability 2013, 5, 3302-3327. [CrossRef]

5. Food and Agriculture Organization of the United Nations (FAO). The State of the World's Land and Water Resources for Food and Agriculture: Managing Systems at Risk; Earthscan: London, UK, 2011.

6. Grewal, S.S.; Grewal, P.S. Can cities become self-reliant in food? Cities 2012, 29, 1-11. [CrossRef]

7. Haberman, D.; Gillies, L.; Canter, A.; Rinner, V.; Pancrazi, L.; Martellozzo, F. The potential of urban agriculture in Montréal: A quantitative assessment. Int. J. Geo-Inf. 2014, 3, 1101-1117. [CrossRef]

8. Lovell, S.T. Multifunctional urban agriculture for sustainable land use planning in the United States. Sustainability 2010, 2, 2499-2522. [CrossRef]

9. Russo, A.; Escobedo, F.J.; Cirella, G.T.; Zerbe, S. Edible green infrastructure: An approach and review of provisioning ecosystem services and disservices in urban environments. Agric. Ecosyst. Environ. 2017, 242, 53-66. [CrossRef]

10. Worldwatch Institute. State of the World 2011. Innovations that Nourish the Planet; Worldwatch Institute: Washington, DC, USA, 2011.

11. Dutt, A. The Future of Food in Cities: Urban Agriculture. Available online: http://www.ipsnews.net/2016/ 07 / the-future-of-food-in-cities-urban-agriculture/ (accessed on 24 May 2018).

12. European Commission. Guidelines on Best Practice to Limit, Mitigate or Compensate Soil Sealing (Commission Staff Working Document); EC: Brussels, Belgium, 2012.

13. United Nations. Resolution Adopted by the General Assembly on 25 September 2015. Transforming Our World: The 2030 Agenda for Sustainable Development; United Nations: New York, NY, USA, 2015.

14. Mok, H.-F.; Williamson, V.G.; Grove, J.R.; Burry, K.; Barker, S.F.; Hamilton, A.J. Strawberry fields forever? Urban agriculture in developed countries: A review. Agron. Sustain. Dev. 2014, 34, 21-43. [CrossRef]

15. Poulsen, M.N. Cultivating citizenship, equity, and social inclusion? Putting civic agriculture into practice through urban farming. Agric. Hum. Values 2017, 34, 135-148. [CrossRef]

16. Forster, T.H.; Hussein, K.; Mattheisen, E. City region food systems: An inclusive and integrated approach to improving food systems and urban-rural linkages. Urban Agric. Mag. 2015, 29, 8-11.

17. Orsini, F.; Kahane, R.; Nono-Womdim, R.; Gianquinto, G. Urban agriculture in the developing world: A review. Agron. Sustain. Dev. 2013, 33, 695-720. [CrossRef] 
18. European Commission. Towards an EU Research and Innovation Policy Agenda for Nature-Based Solutions E Re-Naturing Cities: Final Report of the Horizon 2020 Expert Group on 'nature-Based Solutions and Re-Naturing Cities'; EC: Brussels, Belgium, 2015.

19. Kabisch, N.; Frantzeskaki, N.; Pauleit, S.; Naumann, S.; Davis, M.; Artmann, M.; Haase, D.; Knapp, S.; Korn, H.; Stadler, J.; et al. Nature-based solutions to climate change mitigation and adaptation in urban areas: Perspectives on indicators, knowledge gaps, barriers, and opportunities for action. Ecol. Soc. 2016, 21. [CrossRef]

20. Santiago Fink, H. Human-nature for climate action: Nature-based solutions for urban sustainability. Sustainability 2016, 8, 254. [CrossRef]

21. Raymond, C.M.; Berry, P.; Breil, M.; Nita, M.R.; Kabisch, N.; de Bel, M.; Enzi, V.; Frantzeskaki, N.; Geneletti, D.; Cardinaletti, M.; et al. An Impact Evaluation Framework to Support Planning and Evaluation of Nature-Based Solutions Projects; Centre for Ecology \& Hydrology: Wallingford, UK, 2017.

22. Eggermont, H.; Balian, E.; Azevedo, J.M.N.; Beumer, V.; Brodin, T.; Claudet, J.; Fady, B.; Grube, M.; Keune, H.; Lamarque, P.; et al. Nature-based solutions: New influence for environmental management and research in Europe. GAIA-Ecol. Perspect. Sci. Soc. 2015, 24, 243-248. [CrossRef]

23. Lin, B.B.; Philpott, S.M.; Jha, S. The future of urban agriculture and biodiversity-ecosystem services: Challenges and next steps. Basic Appl. Ecol. 2015, 16, 189-201. [CrossRef]

24. Pourias, J.; Aubry, C.; Duchemin, E. Is food a motivation for urban gardeners? Multifunctionality and the relative importance of the food function in urban collective gardens of Paris and Montreal. Agric. Hum. Values 2016, 33, 257-273. [CrossRef]

25. Kabisch, N.; Qureshi, S.; Haase, D. Human-environment interactions in urban green spaces-A systematic review of contemporary issues and prospects for future research. Environ. Impact Assess. Rev. 2015, 50, $25-34$. [CrossRef]

26. Haase, D. Nature-Based Solutions for Cities: A New Tool for Sustainable Urban Land Development? UGEC VIEWPOINTS, 17 May 2016. Available online: https:/ /ugecviewpoints.wordpress.com/2016/05/17/naturebased-solutions-for-cities-a-new-tool-for-sustainable-urban-land-development/ (accessed on 24 May 2018).

27. Nesshöver, C.; Assmuth, T.; Irvine, K.N.; Rusch, G.M.; Waylen, K.A.; Delbaere, B.; Haase, D.; Jones-Walters, L.; Keune, H.; Kovacs, E.; et al. The science, policy and practice of nature-based solutions: An interdisciplinary perspective. Sci. Total Environ. 2017, 579, 1215-1227. [CrossRef] [PubMed]

28. Millennium Ecosystem Assessment. Ecosystems and Human Well-Being: Synthesis. A Report of the Millennium Ecosystem Assessment; Island Press: Washington, DC, USA, 2005.

29. Hansen, R.; Pauleit, S. From multifunctionality to multiple ecosystem services? A conceptual framework for multifunctionality in green infrastructure planning for urban areas. Ambio 2014, 43, 516-529. [CrossRef] [PubMed]

30. Hansen, R.; Frantzeskaki, N.; McPhearson, T.; Rall, E.; Kabisch, N.; Kaczorowska, A.; Kain, J.-H.; Artmann, M.; Pauleit, S. The uptake of the ecosystem services concept in planning discourses of European and American cities. Ecosyst. Serv. 2015, 12, 228-246. [CrossRef]

31. Foley, J.A.; Ramankutty, N.; Brauman, K.A.; Cassidy, E.S.; Gerber, J.S.; Johnston, M.; Mueller, N.D.; O'Connell, C.; Ray, D.K.; West, P.C.; et al. Solutions for a cultivated planet. Nature 2011, 478, 337. [CrossRef] [PubMed]

32. International Union for Conservation of Nature. Nature-Based Solutions. Available online: https://www. iucn.org/regions/europe/our-work/nature-based-solutions (accessed on 24 May 2018).

33. ICLEI. Nature-Based Solutions for Sustainable Urban Development. ICLEI Briefing Sheet, March 2017. Available online: https://unfccc.int/files/parties_observers/submissions_from_observers/application/ pdf/777.pdf (accessed on 24 May 2018).

34. European Commission. Communication from the Commission to the European Parliament, the Council, the Economic and Social Committee and the Committee of the Regions. Our Life Insurance, Our Natural Capital: An EU Biodiversity Strategy to 2020. COM(2011) 244 Final; European Commission: Brussels, Belgium, 2011.

35. European Commission. Communication from the Commission to the European Parliament, the Council, the European Economic and Social Committee and the Committee of the Regions. Green Infrastructure (GI)_Enhancing Europe's Natural Capital. COM(2013) 249 Final; European Commission: Brussels, Belgium, 2013. 
36. Huang, J.; Tichit, M.; Poulot, M.; Darly, S.; Li, S.; Petit, C.; Aubry, C. Comparative review of multifunctionality and ecosystem services in sustainable agriculture. J. Environ. Manag. 2015, 149, 138-147. [CrossRef] [PubMed]

37. Bastian, O.; Syrbe, R.-U.; Rosenberg, M.; Rahe, D.; Grunewald, K. The five pillar EPPS framework for quantifying, mapping and managing ecosystem services. Ecosyst. Serv. 2013, 4, 15-24. [CrossRef]

38. Kambites, C.; Owen, S. Renewed prospects for green infrastructure planning in the UK. Plan. Pract. Res. 2006, 21, 483-496. [CrossRef]

39. Zanon, B.D.B.; Roeffen, B.; Czapiewska, K.M.; de Graaf-Van Dinther, R.E.; Mooj, P.R. Potential of floating production for delta and coastal cities. J. Clean. Prod. 2017, 151, 10-20. [CrossRef]

40. Halloran, A.; Magid, J. The role of local government in promoting sustainable urban agriculture in Dar es Salaam and Copenhagen. Geogr. Tidsskr. 2013, 113, 121-132. [CrossRef]

41. Shava, S.; Krasny, M.E.; Tidball, K.G.; Zazu, C. Agricultural knowledge in urban and resettled communities: Applications to social-ecological resilience and environmental education. Environ. Educ. Res. 2010, 16, 575-589. [CrossRef]

42. Rosenzweig, C.; Solecki, W.D.; Hammer, S.A.; Mehrotra, S. Climate Change and Cities: First Assessment Report of the Urban Climate Change Research Network; Cambridge University Press: Cambridge, UK, 2011.

43. Lee, G.-G.; Lee, H.-W.; Lee, J.-H. Greenhouse gas emission reduction effect in the transportation sector by urban agriculture in Seoul, Korea. Landsc. Urban Plan. 2015, 140, 1-7. [CrossRef]

44. Cleveland, D.A.; Phares, N.; Nightingale, K.D.; Weatherby, R.L.; Radis, W.; Ballard, J.; Campagna, M.; Kurtz, D.; Livingston, K.; Riechers, G.; et al. The potential for urban household vegetable gardens to reduce greenhouse gas emissions. Landsc. Urban Plan. 2017, 157, 365-374. [CrossRef]

45. Llorach-Massana, P.; Muñoz, P.; Riera, M.R.; Gabarrell, X.; Rierdevall, J.; Montero, J.I.; Villalba, G. $\mathrm{N}_{2} \mathrm{O}$ emissions from protected soilless crops for more precise food and urban agriculture life cycle assessments. J. Clean. Prod. 2017, 149, 1118-1126. [CrossRef]

46. Waffle, A.D.; Corry, R.C.; Gillespie, T.J.; Brown, R.D. Urban heat island as agricultural opportunities: An innovative approach. Landsc. Urban Plan. 2017, 161, 103-114. [CrossRef]

47. Lin, B.B.; Egerer, M.H.; Liere, H.; Jha, S.; Biechier, P.; Philpott, S.M. Local- and landscape-scale land cover affects microclimate and water use in urban areas. Sci. Total Environ. 2018, 610-611, 570-575. [CrossRef] [PubMed]

48. Food and Agriculture Organization of the United Nations(FAO). Trade Reforms and Food Security: Conceptualizing the Linkages; FAO: Rome, Italy, 2003.

49. Saha, M.; Eckelman, M.J. Growing fresh fruits and vegetables in an urban landscape: A geospatial assessment of ground level and rooftop urban agriculture potential in Boston, USA. Landsc. Urban Plan. 2017, 165, 130-141. [CrossRef]

50. Gondhalekar, D.; Ramsauer, T. Nexus city: Operationalizing the urban water-energy-food nexus for climate change adaption in Munich, Germany. Urban Clim. 2017, 19, 28-40. [CrossRef]

51. Ward, J.D.; Ward, P.J.; Mantzioris, E.; Saint, C. Optimising diet decisions and urban agriculture using linear programming. Food Secur. 2014, 6, 701-718. [CrossRef]

52. Astee, L.Y.; Kishnani, N.T. Building integrated agriculture utilising rooftops for sustainable food crop cultivation in Singapore. J. Green Build. 2010, 5, 105-113. [CrossRef]

53. Nadal, A.; Alamús, R.; Pipia, L.; Ruiz, A.; Corbera, J.; Cuerva, E.; Rieradevall, J.; Josa, A. Urban planning and agriculture. Methodology for assessing rooftop greenhouse potential of non-residential areas using airborne sensors. Sci. Total Environ. 2017, 601-602, 493-507. [CrossRef] [PubMed]

54. McClintock, N.; Mahmoudi, D.; Simpson, M.; Santos, J.P. Socio-spatial differentiation in the sustainable city: A mixed-methods assessment of residential gardens in metropolitan Portland, Oregon, USA. Landsc. Urban Plan. 2016, 148, 1-16. [CrossRef]

55. Metcalf, S.S.; Widener, M.J. Growing Buffalo's capacity for local food: A systems framework for sustainable agriculture. Appl. Geogr. 2011, 31, 1242-1251. [CrossRef]

56. Corrigan, M.P. Growing what you eat: Developing community gardens in Baltimore, Maryland. Appl. Geogr. 2011, 31, 1232-1241. [CrossRef]

57. Kortright, R.; Wakefield, S. Edible backyards. A qualitative study of household food growing and its contributions to food security. Agric. Hum. Values 2016, 28, 39-53. [CrossRef] 
58. Aubry, C.; Kebir, L. Shortening food supply chains: A means for maintainig agriculture close to urban areas? The case of the French metropolitan area of Paris. Food Policy 2013, 41, 85-93. [CrossRef]

59. Keesstra, S.; Nunes, J.; Novara, A.; Finger, D.; Avelar, D.; Kalantari, Z.; Cerdà, A. The superior effect of nature based solutions in land management for enhancing ecosystem services. Sci. Total Environ. 2018, 610, 997-1009. [CrossRef] [PubMed]

60. Camps-Calvet, M.; Langmeyer, J.; Calvet-Mir, L.; Gómez-Baggethun, E. Ecosystem services provided by urban gardens in Barcelona, Spain: Insights for policy and planning. Environ. Sci. Sci. 2016, 62, 14-23. [CrossRef]

61. Gregory, M.M.; Leslie, T.W.; Drinkwater, L.E. Agroecological and social characteristics of New York City community gardens: Contributions to urban food security, ecosystem services, and environmental education. Urban Ecosyst. 2016, 19, 763-794. [CrossRef]

62. Clarke, L.W.; Jenerette, G.D. Biodiversity and direct ecosystem service regulation in the community gardens of Los Angeles, CA. Landsc. Ecol. 2015, 30, 637-653. [CrossRef]

63. Egerer, M.H.; Bichier, P.; Philpott, S.M. Landscape and local habitat correlates of lady beetle abundance and species richness in urban agriculture. Ann. Entomol. Soc. Am. 2017, 110, 97-103. [CrossRef]

64. Woods, M.E.; Ata, R.; Teitel, Z.; Arachchige, N.M.; Yang, Y.; Raychaba, B.E.; Kuhns, J.; Campbell, L.G. Crop diversity and plant-plant interactions in urban allotment gardens. Renew. Agric. Food Syst. 2016, 31, 540-549. [CrossRef]

65. Quistberg, R.D.; Bichier, P.; Philpott, S.M. Landscape and local correlates of bee abundance and species richness in urban grounds. Environ. Entomol. 2016, 45, 592-601. [CrossRef] [PubMed]

66. Richards, P.J.; Farrell, C.; Tom, M.; Williams, N.S.G.; Fetcher, T.D. Vegetable raingardens can produce food and reduce stormwater runoff. Urban For. Urban Green. 2015, 14, 646-654. [CrossRef]

67. Gittleman, M.; Farmer, C.J.Q.; Kremer, P.; McPhearson, T. Estimating stormwater runoff for community gardens in New York City. Urban Ecosyst. 2017, 20, 129-139. [CrossRef]

68. Edmondson, J.L.; Davies, Z.G.; Gaston, K.J.; Leake, J.R. Urban cultivation in allotments maintains soil qualities adversely affected by conventional agriculture. J. Appl. Ecol. 2015, 51, 880-889. [CrossRef] [PubMed]

69. Reeves, J.; Cheng, Z.; Kovach, J.; Kleinhenz, M.D.; Grewal, P.S. Quantifying soil health and tomato crop productivity in urban community and market gardens. Urban Ecosyst. 2015, 17, 221-238. [CrossRef]

70. Tsilini, V.; Papantoniou, S.; Kolokotsa, D.-D.; Maria, E.-A. Urban gardens as a solution to energy poverty and urban heat island. Sustain. Cities Soc. 2015, 14, 323-333. [CrossRef]

71. Potter, A.; LeBuhn, G. Pollination service to urban agriculture in San Francisco, CA. Urban Ecosyst. 2015, 18, 885-893. [CrossRef]

72. Dennis, M.; James, P. Ecosystem services of collectively managed urban gardens: Exploring factors affecting synergies and trade-offs at the site level. Ecosyst. Serv. 2017, 26, 17-26. [CrossRef]

73. Taylor, J.R.; Lovell, S.T.; Wortman, S.E.; Chan, M. Ecosystem services and tradeoffs in the home food gardens of African American, Chinese-origin and Mexican-origin households in Chicago, IL. Renew. Agric. Food Syst. 2017, 32, 69-86. [CrossRef]

74. Taylor, J.R.; Lovell, S.T. Urban home gardens in the global north: A mixed methods study of ethnic and migrant home gardens in Chicago, IL. Renew. Agric. Food Syst. 2015, 30, 22-32. [CrossRef]

75. Davis, A.Y.; Lonsdorf, E.V.; Shierk, C.R.; Matteson, K.C.; Taylor, J.R.; Lovell, S.T.; Minor, E.S. Enhancing pollination supply in an urban ecosystem through landscape modifications. Landsc. Urban Plan. 2017, 162, 157-166. [CrossRef]

76. Breuste, J.H.; Artmann, M. Allotment gardens contribute to urban ecosystem service: Case study Salzburg, Austria. J. Urban Plan. Dev. 2015, 141. [CrossRef]

77. Ruoso, L.-E.; Plant, R.; Maurel, P.; Dupaquier, C.; Roche, P.K.; Bonin, M. Reading ecosystem services at the local scale through a territorial approach: The case of peri-urban agriculture in the Thau Lagoon, southern France. Ecol. Soc. 2015, 20. [CrossRef]

78. Orsini, F.; Gasperi, D.; Marchetti, L.; Piovene, C.; Draghetti, S.; Ramazzotti, S.; Bazzocchi, G.; Gianquinto, G. Exploring the production capacity of rooftop gardens (RTGs) in urban agriculture: The potential impact on food and nutrition security, biodiversity and other ecosystem services in the city of Bologna. Food Secur. 2014, 6, 781-792. [CrossRef] 
79. Tilman, D.; Balzer, C.; Hill, J.; Befort, B.L. Global food demand and the sustainable intensification of agriculture. Proc. Natl. Acad. Sci. USA 2011, 108, 20260-20264. [CrossRef] [PubMed]

80. Arrobas, M.; Lopes, H.; Rodrigues, M.Â. Urban agriculture in Bragança, northeast Portugal: Assessing the nutrient dynamic in the soil and plants, and their contamination with trace metals. Biol. Argic. Hortic. 2017, 33, 1-13. [CrossRef]

81. Rusciano, V.; Civero, G.; Scarpato, D. Urban gardens and environmental sustainability: An empirical research of Campania region. Qual.-Access Success 2017, 18, 376-381. [CrossRef]

82. Orlando, G. Sustainable food vs. unsustainable politics in the city of Palermo: The case of an organic farmers' market. City Soc. 2011, 23, 173-191. [CrossRef]

83. Huang, S.-L.; Yeh, C.-T.; Chang, L.-F. The transition to an urbanizing world and the demand for natural resources. Curr. Opin. Environ. Sustain. 2010, 2, 136-143. [CrossRef]

84. Balda, M.C.; Furubayashi, T.; Nakata, T. A novel approach for analyzing the food-energy nexus through on-farm energy generation. Clean Technol. Environ. Policy 2017, 19, 1003-1019. [CrossRef]

85. Saha, M.; Eckelman, M.J. Geospatial assessment of potential bioenergy crop production on urban marginal land. Appl. Energy 2015, 159, 540-547. [CrossRef]

86. Nadal, A.; Llorach-Massana, P.; Cuerva, E.; López-Capel, E.; Montero, J.I.; Josa, A.; Rieradevall, J.; Royapoor, M. Building integrated rooftop greenhouses: An energy and environmental assessment in the Mediterranean context. Appl. Energy 2017, 187, 338-351. [CrossRef]

87. Sanyé-Mengual, E.; Orsini, F.; Oliver-Solà, J.; Rieradevall, J.; Montero, J.I.; Gianquinto, G. Techniques and crops for efficient rooftop gardens in Bologna, Italy. Agron. Sustain. Dev. 2015, 35, 1477-1488. [CrossRef]

88. Sanyé-Mengual, E.; Oliver-Solà, J.; Montero, J.I.; Rieradevall, J. An environmental and economic life cycle assessment of rooftop greenhouse (RTG) implementation in Barcelona, Spain. Assessing new forms of urban agriculture from the greenhouse structure to the final product level. Int. J. Life Cycle Assess. 2015, 20, 350-366. [CrossRef]

89. Sanyé-Mengual, E.; Oliver-Solà, J.; Montero, J.I.; Riradevall, J. The role of interdisciplinarity in evaluating the sustainability of urban rooftop agriculture. Future Food J. Food Agric. Soc. 2017, 5, 46-58.

90. Liebman, M.B.; Jonasson, O.J.; Wiese, R.N. The urban stormwater farm. Water Sci. Technol. 2011, 64, $239-246$. [CrossRef] [PubMed]

91. Lupia, F.; Baiocchi, V.; Lelo, K.; Pulighe, G. Exploring rooftop rainwater harvesting potential for food production in urban areas. Agriculture 2017, 7, 46. [CrossRef]

92. Garcia, X.; Llausàs, L.; Ribas, A.; Saurí, D. Watering the garden: Preferences for alternative sources in suburban areas of the Mediterranean coast. Local Environ. 2015, 20, 548-564. [CrossRef]

93. Morckel, V. Community gardens or vacant lots? Rethinking the attractiveness and seasonality of green land uses in distressed neighborhoods. Urban For. Urban Green. 2015, 14, 714-721. [CrossRef]

94. Foo, K.; Martin, D.; Wool, C.; Polsky, C. Reprint of "the production of urban vacant land: Relational placemaking in Boston, MA neighborhoods". Cities 2014, 40, 175-182. [CrossRef]

95. Gasperi, D.; Pennisi, G.; Rizzati, N.; Magrefi, F.; Bazzocchi, G.; Mezzacapo, U.; Stefani, M.C.; Sanyé-Mengual, E.; Orsini, F.; Gianquinto, G. Towards regenerated and productive vacant areas through urban horticulture: Lessons from Bologna, Italy. Sustainability 2016, 8, 1347. [CrossRef]

96. Kremera, P.; Hamstead, Z.A.; McPhearson, T. A social-ecological assessment of vacant lots in New York City. Landsc. Urban Plan. 2013, 120, 218-223. [CrossRef]

97. Saporito, E. Ortialti as urban regeneration devices: An action-research study on rooftop farming in Turin. Future Food J. Food Agric. Soc. 2017, 5, 59-69.

98. Yoo, H. A study on the prefab greenhouse on the rooftop for the neighborhood regeneration in Seoul, South Korea. Int. J. Smart Home 2016, 10, 253-266. [CrossRef]

99. Roth, M.; Frixen, M.; Tobisch, C.; Scholle, T. Finding spaces for urban food production-matching spatial and stakeholder analysis with urban agriculture approaches in the urban renewal area of Dortmund-Hörde, Germany. Future Food J. Food Agric. Soc. 2015, 3, 79-88.

100. Demailly, K.-E.; Darly, S. Urban agriculture on the move in Paris: The routes of temporary gardening in the neoliberal city. Int. J. Crit. Geogr. 2017, 16, 332-361. 
101. Kato, Y.; Passidomo, C.; Harvey, D. Political gardening in a post-disaster city: Lessons from New Orleans. Urban Stud. 2014, 51, 1833-1849. [CrossRef]

102. Thomas, E.C.; Lavkulich, L.M. Community considerations for quinoa production in the urban environment. Can. J. Plant Sci. 2015, 95, 397-404. [CrossRef]

103. Rolf, W.; Peters, D.; Lenz, R.; Pauleit, S. Farmland-An elephant in the room of urban green infrastructure? Lessons learned from connectivity analysis in three German cities. Ecol. Indic. 2017. [CrossRef]

104. Dobbs, C.; Kendal, D.; Nitschke, C.R. Multiple ecosystem services and disservices of the urban forest establishing their connections with landscape structure and sociodemographics. Ecol. Indic. 2014, 43, 44-55. [CrossRef]

105. Clark, K.H.; Nicholas, K.A. Introducing urban food forestry: A multifunctional approach to increase food security and provide ecosystem services. Landsc. Ecol. 2013, 28, 1649-1669. [CrossRef]

106. Wielemaker, R.C.; Weijma, J.; Zeeman, G. Harvest to harvest: Recovering nutrients with new sanitation systems for reuse on urban agriculture. Resour. Conserv. Recycl. 2018, 128, 426-437. [CrossRef]

107. McLain, R.; Poe, M.; Hurley, P.T.; Lecompte-Mastenbrook, J.; Emery, M.R. Producing edible landscapes in Seattle's urban forest. Urban For. Urban Green. 2012, 11, 187-194. [CrossRef]

108. Huang, D.; Drescher, M. Urban crops and livestock: The experiences, challenges, and opportunities of urban planning for urban agriculture in two Canadian provinces. Land Use Policy 2014, 43, 1-14. [CrossRef]

109. Cohen, N.; Reynolds, K. Resource needs for a socially just and sustainable urban agriculture system: Lessons from New York City. Renew. Agric. Food Syst. 2014, 30, 103-114. [CrossRef]

110. Campbell, L.K. Getting farming on the agenda: Planning, policymaking, and governance practices of urban agriculture in New York City. Urban For. Urban Green. 2016, 19, 295-305. [CrossRef]

111. Pawlikowska-Piechotka, A. Urban greens and sustainable land policy management (case study in Warsaw). European Countryside 2012, 4, 251-268. [CrossRef]

112. Wekerle, G.R.; Classens, M. Food production in the city: (Re)negotiating land, food and property. Local Environ. 2014, 20, 1175-1193. [CrossRef]

113. Cretella, A.; Buenger, M.S. Food as creative city politics in the city of Rotterdam. Cities 2016, 51, 1-10. [CrossRef]

114. Prové, C.; Dessein, J.; Krom, M.D. Taking context into account in urban agriculture governance: Case studies of Warsaw (Poland) and Ghent (Belgium). Land Use Policy 2016, 56, 16-26. [CrossRef]

115. Mikulec, P.; Diduck, A.R.; Froese, B.; Unger, H.; MacKenzie, K. Legal and policy barriers to community gardening in Winnipeg, Canada. Can. J. Urban Res. 2015, 22, 69-89.

116. Wästfelt, A.; Zhang, Q. Reclaiming localisation for revitalising agriculture: A case study of peri-urban agricultural change in Gothenburg, Sweden. J. Rural Stud. 2016, 47, 172-185. [CrossRef]

117. Olsson, E.G.A.; Kerselaers, E.; Kristense, L.S.; Primdahl, J.; Rogge, E.; Wästfelt, A. Peri-urban food production and its relation to urban resilience. Sustainability 2016, 8, 1340. [CrossRef]

118. Schwaab, J.; Deb, K.; Goodman, E.; Lauterbach, S.; van Strien, M.; Grêt-Regamey, A. Reducing the loss of agricultural productivity due to compact urban development in municipalities of Switzerland. Comput. Environ. Urban Syst. 2017, 65, 162-177. [CrossRef]

119. La Rosa, D.; Privitera, R. Characterization of non-urbanized areas for land-use planning of agricultural and green infrastructure in urban contexts. Landsc. Urban Plan. 2013, 109, 94-106. [CrossRef]

120. Bretzel, F.; Calderisi, M.; Scantena, M.; Pini, R. Soil quality is key for planning and managing urban allotments intended for the sustainable production of home-consumption vegetables. Environ. Sci. Pollut. Res. 2016, 23, 17753-17760. [CrossRef] [PubMed]

121. Oka, G.A.; Thomas, L.; Lavkulich, L.M. Soil assessment for urban agriculture: A Vancouver case study. J. Soil Sci. Plant Nutr. 2014, 14, 657-669. [CrossRef]

122. Boente, C.; Matanzas, N.; García-Gonzáles, N.; Rodríguez-Valdés, E.; Gallego, J.R. Trace elements of concern affecting urban agriculture in industrialized areas: A multivariate approach. Chemosphere 2017, 183, 546-556. [CrossRef] [PubMed]

123. De Miguel, E.; Izquierdo, M.; Gómez, A.; Mingot, J.; Barrio-Parra, F. Risk assessment from exposure to arsenic, antimony, and selenium in urban gardens (Madrid, Spain). Environ. Toxicol. Chem. 2017, 36, 544-550. [CrossRef] [PubMed] 
124. Milliron, B.-J.; Vitolins, M.Z.; Gamble, E.; Jones, R.; Chenault, M.C.; Tooze, J.A. Process evaluation of a community garden at an urban outpatient clinic. J. Community Health 2017, 4, 639-648. [CrossRef] [PubMed]

125. Guerlain, M.A.; Campbell, C. From sanctuaries to prefigurative social change: Creating health-enabling spaces in East London community gardens. J. Soc. Polit. Psycol. 2016, 1, 220-237. [CrossRef]

126. Litt, J.S.; Schmiege, S.J.; Hale, J.W.; Buchenau, M.; Sancar, F. Exploring ecological, emotional and social levers of self-rated health for urban gardeners and non-gardeners: A path analysis. Soc. Sci. Med. 2015, 114, 1-8. [CrossRef] [PubMed]

127. Soga, M.; Cox, D.T.C.; Yamaura, Y.; Gaston, K.J.; Kurisu, K.; Hanaki, K. Health benefits of urban allotment gardening: Improved physical and psychological well-being and social integration. Int. J. Environ. Res. Public Health 2017, 14, 71. [CrossRef] [PubMed]

128. Nordh, H.; Wiklund, K.T.; Koppang, K.E. Norwegian allotment gardens-A study of motives and benefits. Landsc. Res. 2016, 41, 853-868. [CrossRef]

129. Hale, J.; Knapp, C.; Bardwell, L.; Buchenau, M.; Marshall, J.; Sancar, F.; Litt, J.S. Connecting food environments and health through the relational nature of aesthetics: Gaining insight through the community gardening experience. Soc. Sci. Med. 2011, 72, 1853-1863. [CrossRef] [PubMed]

130. Middling, S.; Bailey, J.; Maslin-Prothero, S.; Scharf, T. Gardening and the social engagement of older people. Work. Older People 2011, 3, 112-122. [CrossRef]

131. Chan, J.; DuBois, B.; Tidball, K.G. Refuges of local resilience: Community gardens in post-Sandy New York City. Urban For. Urban Green. 2015, 14, 625-635. [CrossRef]

132. Guitart, D.A.; Pickering, C.M.; Byrne, J.A. Color me healthy: Food diversity in school community gardens in two rapidly urbanising Australian Cities. Health Place 2014, 26, 110-117. [CrossRef] [PubMed]

133. Van der Jagt, A.P.N.; Szaraz, L.R.; Delshammar, T.; Cvejić, R.; Santos, A.; Goodness, J.; Buijs, A. Cultivating nature-based solutions: The governance of communal urban gardens in the European Union. Environ. Res. 2017, 159, 264-275. [CrossRef] [PubMed]

134. Da Silva, I.M.; Fernandes, C.O.; Castiglione, B.; Costa, L. Characteristics and motivations of potential users of urban allotment gardens: The case of Vila Nova de Gaia municipal network of urban allotment gardens. Urban For. Urban Green. 2016, 20, 56-64. [CrossRef]

135. Cabannes, Y.; Raposo, I. Peri-urban agriculture, social inclusion of migrant population and right to the city: Practices in Lisbon and London. City 2013, 17, 235-250. [CrossRef]

136. Chan, J.; Pennisi, L.; Francis, C.A. Social-ecological refuges: Reconnecting in community gardens in Lincoln, Nebraska. J. Ethnobiol. 2016, 36, 842-860. [CrossRef]

137. Brown-Fraser, S.; Forrester, I.; Rowel, R.; Richardson, A.; Spence, A.N. Development of a community organic vegetable garden in Baltimore, Maryland: A student service-learning approach to community engagement. J. Hunger Environ. Nutr. 2105, 10, 409-436. [CrossRef]

138. Bendt, P.; Barthel, S.; Colding, J. Civic greening and environmental learning in public-access community gardens in Berlin. Landsc. Urban Plan. 2013, 109, 18-30. [CrossRef]

139. Comstock, N.; Dickinson, L.M.; Marshall, J.A.; Soobader, M.-J.; Turbin, M.S.; Buchenau, M.; Litt, J.S. Neighborhood attachment and its correlates: Exploring neighborhood conditions, collective efficacy, and gardening. J. Environ. Psychol. 2010, 30, 435-442. [CrossRef]

140. Camps-Calvet, M.; Langemeyer, J.; Calvet-Mir, L.; Gómez-Baggethun, E.; March, H. Sowing resilience and contestation in times of crises: The case of urban gardening movements in Barcelona. Partecip. Conflitto 2015, 8, 417-442. [CrossRef]

141. McIvor, D.W.; Hale, J. Urban agriculture and the prospects for deep democracy. Agric. Hum. Values 2015, 32, 727-741. [CrossRef]

142. Reynolds, K. Disparity despite diversity: Social injustice in New York City's urban agriculture system. Antipode 2015, 47, 240-259. [CrossRef]

143. Kato, Y. Not just the price of food: Challenges of an urban agriculture organization in engaging local residents. Sociol. Inq. 2013, 83, 369-391. [CrossRef]

144. White, J.T.; Bunn, C. Growing in Glasgow: Innovative practices and emerging policy pathways for urban agriculture. Land Use Policy 2017, 68, 334-344. [CrossRef] 
145. Farges, G. Convergence on sustainable lifestyles? Mechanisms of change and resistance in a French allotment. Sociol. Rural. 2015, 55, 1-21. [CrossRef]

146. Specht, K.; Weith, T.; Swoboda, K.; Siebert, R. Socially acceptable urban agriculture businesses. Agron. Sustain. Dev. 2016, 36, 17. [CrossRef]

147. Vitiello, D.; Wolf-Powers, L. Growing food to grow cities? The potential of agriculture foreconomic and community development in the urban United States. Community Dev. J. 2014, 49, 508-523. [CrossRef]

148. Pölling, B.; Mergenthaler, M.; Lorleberg, W. Professional urban agriculture and its characteristic business models in Metropolis Ruhr, Germany. Land Use Policy 2016, 58, 366-379. [CrossRef]

149. Corcoran, M.P.; Kettle, P.H.; O'Callaghan, C. Green shoots in vacant plots? Urban agriculture and austerity in post-crash Ireland. Int. J. Crit. Geogr. 2017, 16, 305-331.

150. Thomaier, S.; Specht, K.; Henckel, D.; Dierich, A.; Siebert, R.; Freisinger, U.B.; Sawicka, M. Farming in and on urban buildings: Present practice and specific novelties of zero-acreage farming (zfarming). Renew. Agric. Food Syst. 2015, 30, 43-54. [CrossRef]

151. Specht, K.; Siebert, R.; Thomaier, S.; Freisinger, U.B.; Sawicka, M.; Dierich, A.; Henckel, D.; Busse, M. Zero-acreage farming in the city of Berlin: An aggregated stakeholder perspective on potential benefits and challenge. Sustainability (Switzerland) 2015, 7, 4511-4523. [CrossRef]

152. Laidlaw, J.; Magee, L. Towards urban food sovereignty: The trials and tribulations of community-based aquaponics enterprises in Milwaukee and Melbourne. Local Environ. 2014, 21, 573-590. [CrossRef]

153. Walker, S. Urban agriculture and the sustainability fix in Vancouver and Detroit. Urban Geogr. 2016, 37, 163-182. [CrossRef]

154. Weissman, E. Entrepreneurial endeavors: (Re)producing neoliberalization through urban agriculture youth programming in Brooklyn. Environ. Educ. Res. 2015, 21, 351-364. [CrossRef]

155. Giacchè, G.; Paffarini, C.; Torquati, B. Cultivating changes: Urban agriculture as a tool for socio-spatial transformation. Future Food J. Food Agric. Soc. 2017, 5, 8-20.

156. Opitz, I.; Specht, K.; Berges, R.; Siebert, R.; Piorr, A. Toward sustainability: Novelties, areas of learning and innovation in urban agriculture. Sustainability 2016, 8, 356. [CrossRef]

157. Russo, P.; Tomaselli, G.; Pappalardo, G. Marginal periurban agricultural areas: A support method for landscape planning. Land Use Policy 2014, 41, 97-109. [CrossRef]

158. Pfeiffer, A.; Silva, E.; Colquhoun, J. Innovation in urban agricultural practices: Responding to diverse production environments. Renew. Agric. Food Syst. 2014, 30, 79-91. [CrossRef]

159. Gray, L.; Guzman, P.; Glowa, K.M.; Drevno, A.G. Can home gardens scale up imto movements for social change? The role of home gardens in providing food security and community change in San Jose, California. Local Environ. 2014, 19, 187-203. [CrossRef]

160. Kaiser, M.L.; Williams, M.L.; Basta, N.; Hand, M.; Huber, S. When vacant lots become urban gardens: Characterizing the perceived and actual food safety concerns of urban agriculture in Ohio. J. Food Prot. 2015, 78, 2070-2080. [CrossRef] [PubMed]

161. Liquete, C.; Udias, A.; Conte, G.; Grizzetti, B.; Masi, F. Integrated valuation of a nature-based solution for water pollution control. Highlighting hidden benefits. Ecosyst. Serv. 2016, 22, 392-401. [CrossRef]

162. Ackerman, K.; Conrad, M.; Culligan, P.; Plunz, R.; Sutto, M.-P.; Whittinghill, L. Sustainable food systems for future cities: The potential of urban agriculture. Econ. Soc. Rev. 2014, 45, 189-206.

163. Parece, T.E.; Campbell, J.B. Geospatial evaluation for urban agriculture land inventory: Roanoke, Virginia USA. Int. J. Appl. Geospat. Res. 2017, 8, 43-63. [CrossRef]

164. Specht, K.; Siebert, R.; Thomaier, S. Perception and acceptance of agricultural production in and on urban buildings (Zfarming): A qualitative study from Berlin, Germany. Agric. Hum. Values 2016, 33, 753-769. [CrossRef]

165. Cabral, I.; Kein, J.; Engelmann, R.; Kraemer, R.; Siebert, J.; Bonn, A. Ecosystem services of allotment and community gardens: A Leipzig, Germany case study. Urban For. Urban Green. 2017, 23, 44-56. [CrossRef]

166. Pennisi, G.; Orsini, F.; Gasperi, D.; Mancarella, S.; Sanoubar, R.; Antisari, L.V.; Vianello, G.; Gianquinto, G. Soilless system on peat reduce trace metals in urban-grown food: Unexpected evidence for a soil origin of plant contamination. Agron. Sustain. Dev. 2016, 36, 56. [CrossRef]

167. Cvejić, R.; Železnikar, Š.; Nastran, M.; Rehberger, V.; Pintar, M. Urban agriculture as a tool for facilitated urban greening of sites in transition: A case study. Urbani Izziv 2015, 26, 84-97. [CrossRef] 
168. Algert, S.J.; Baameur, A.; Renvall, M.J. Vegetable output and cost savings of community gardens in San Jose, California. J. Acad. Nutr. Diet. 2014, 114, 1072-1076. [CrossRef] [PubMed]

169. Sanyé-Mengual, E.; Cerón-Palma, I.; Oliver-Solà, J.; Montero, J.I.; Rieradevall, J. Environmental analysis of the logistics of agricultural products from roof top greenhouses in Mediterranean urban areas. Sci. Food Agric. 2012, 93, 100-109. [CrossRef] [PubMed]

170. Heraty, J.M.; Ellstrand, N.C. Maize germplasm conservation in Southern California's urban gardens: Introduced diversity beyond ex situ and in situ management. Econ. Bot. 2016, 70, 37-48. [CrossRef] [PubMed]

171. Maes, J.; Jacobs, S. Nature-based solutions for Europe's sustainable development. Conserv. Lett. 2017, 10, 121-124. [CrossRef]

172. Großmann, K.B.; Bontje, M.; Haase, A.; Mykhnenko, V. Shrinking cities: Notes for the further research agenda. Cities 2013, 35, 221-225. [CrossRef]

173. Artmann, M. Spatial dimensions of soil sealing management in growing and shrinking cities-A systemic multi-scale analysis in Germany. Erdkunde 2013, 67, 249-264. [CrossRef]

174. Plant, R.; Walker, J.; Rayburg, S.; Gothe, J.; Leung, T. The wild life of pesticides: Urban agriculture, institutional responsibility, and the future of biodiversity in Sydney's Hawkesbury-Nepean river. Aust. Geogr. 2012, 43, 75-91. [CrossRef]

175. Pulighe, G.; Lupia, F. Mapping spatial patterns of urban agriculture in Rome (Italy) using Google Earth and web-mapping services. Land Use Policy 2016, 59, 49-58. [CrossRef]

176. Fox-Kämper, R.; Wesener, A.; Münderlein, D.; Sondermann, M.; McWilliam, W.; Kirk, N. Urban community gardens: An evaluation of governance approaches and related enablers and barriers at different development stages. Landsc. Urban Plan. 2018, 170, 59-68. [CrossRef]

177. Haase, D.; Larondelle, N.; Andersson, E.; Artmann, M.; Borgström, S.; Breuste, J.; Gomez-Baggethun, E.; Gren, Å.; Hamstead, Z.; Hansen, R.; et al. A quantitative review of urban ecosystem service assessments: Concepts, models, and implementation. Ambio 2014, 43, 413-433. [CrossRef] [PubMed]

178. Von Döhren, P.; Haase, D. Ecosystem disservices research: A review of the state of the art with a focus on cities. Ecol. Indic. 2015, 52, 490-497. [CrossRef]

179. Goldstein, B.; Hauschild, M.; Fernández, J.; Birkved, M. Testing the environmental performance of urban agriculture as a food supply in northern climates. J. Clean. Prod. 2016, 135, 984-994. [CrossRef]

180. Sharma, K.; Cheng, Z.; Grewal, P.S. Relationship between soil heavy metal contamination and soil food web health in vacant lots slated for urban agriculture in two post-industrial cities. Urban Ecosyst. 2015, 3, 835-855. [CrossRef]

181. Izquierdo, M.; De Miguel, E.; Ortega, M.F.; Mingot, J. Bioaccessibility of metals and human health risk assessment in community urban gardens. Chemosphere 2015, 135, 312-318. [CrossRef] [PubMed]

182. Cheng, Z.; Paltseva, A.; Li, I.; Morin, T.; Huot, H.; Egendorf, S.; Su, Z.; Yolanda, R.; Singh, K.; Lee, L.; et al. Trace metal contamination in New York City garden soils. Soil Sci. 2015, 180, 167-174. [CrossRef]

183. Kohrman, H.; Chamberlain, C.P. Heavy metals in produce from urban farms in the San Francisco Bay area. Food Addit. Contam. Part B 2014, 2, 127-134. [CrossRef] [PubMed]

184. Tom, M.; Fletcher, T.D.; McCarthy, D.T. Heavy metal contamination of vegetables irrigated by urban stormwater: A matter of time? PLoS ONE 2104, 11, e112441. [CrossRef] [PubMed]

185. Forslund, A.; Ensink, J.H.J.; Battilani, A.; Kljujev, I.; Gola, S.; Raicevic, V.; Jovanovic, Z.; Stikic, R.; Sandei, L.; Fletcher, T.; et al. Faecal contamination and hygiene aspect associated with the use of treated wastewater and canal water for irrigation of potatoes (Solanum tuberosum). Agric. Water Manag. 2010, 98, 440-450. [CrossRef]

186. Spliethoff, H.M.; Mitchell, R.G.; Ribaudo, L.N.; Taylor, O.; Shayler, H.A.; Greene, V.; Oglesby, D. Lead in New York City community garden chicken eggs: Influential factors and health implications. Environ. Geochem. Health 2104, 4, 633-649. [CrossRef] [PubMed]

187. Warming, M.; Hansen, M.G.; Holm, P.E.; Magid, J.; Hansen, T.H.; Trapp, S. Does intake of trace elements through urban gardening in Copenhagen pose a risk to human health? Environ. Pollut. 2015, 202, 17-23. [CrossRef] [PubMed]

188. Megson, D.; Dack, S.; Moore, M. Limitations of the clea model when assessing human health risks from dioxins and furans in soil at an allotments site in Rochdale, New England. J. Environ. Monit. 2011, 13, 1983-1990. [CrossRef] [PubMed] 
189. Defoe, P.P.; Hettiarachchi, G.M.; Benedict, C.; Martin, S. Safety of gardening on lead- and arsenic-contaminated urban brownfields. J. Environ. Qual. 2014, 43, 2064-2078. [CrossRef] [PubMed]

190. Tornaghi, C.; Van Dyck, B. Research-informed gardening activism: Steering the public food and land agenda. Local Environ. 2015, 20, 1247-1264. [CrossRef]

(c) (c) 2018 by the authors. Licensee MDPI, Basel, Switzerland. This article is an open access article distributed under the terms and conditions of the Creative Commons Attribution (CC BY) license (http:/ / creativecommons.org/licenses/by/4.0/). 